Purdue University

Purdue e-Pubs

Open Access Theses

Theses and Dissertations

Summer 2014

\title{
Spatial and Temporal Distribution of Fungicides Applied to Creeping Bentgrass
}

Kurt Ronald Hockemeyer

Purdue University

Follow this and additional works at: https://docs.lib.purdue.edu/open_access_theses

Part of the Agronomy and Crop Sciences Commons, and the Plant Biology Commons

\section{Recommended Citation}

Hockemeyer, Kurt Ronald, "Spatial and Temporal Distribution of Fungicides Applied to Creeping Bentgrass" (2014). Open Access Theses. 439.

https://docs.lib.purdue.edu/open_access_theses/439

This document has been made available through Purdue e-Pubs, a service of the Purdue University Libraries. Please contact epubs@purdue.edu for additional information. 


\section{PURDUE UNIVERSITY \\ GRADUATE SCHOOL \\ Thesis/Dissertation Acceptance}

This is to certify that the thesis/dissertation prepared

By Kurt Ronald Hockemeyer

Entitled Spatial and temporal distribution of fungicides applied to creeping bentgrass

For the degree of

Master of Science

Is approved by the final examining committee:

Richard Latin

Ronald Turco

Teresa Hughes

To the best of my knowledge and as understood by the student in the Thesis/Dissertation Agreement. Publication Delay, and Certification/Disclaimer (Graduate School Form 32), this thesis/dissertation adheres to the provisions of Purdue University's "Policy on Integrity in Research" and the use of copyrighted material.

\section{Richard Latin}

Approved by Major Professor(s):

Approved by: Peter Goldsbrough

$07 / 21 / 2014$ 
SPATIAL AND TEMPORAL DISTRIBUTION OF FUNGICIDES APPLIED TO CREEPING BENTGRASS

\author{
A Thesis \\ Submitted to the Faculty \\ of \\ Purdue University \\ by \\ Kurt Hockemeyer \\ In Partial Fulfillment of the \\ Requirements for the Degree \\ of \\ Master of Science
}

August 2014

Purdue University

West Lafayette, Indiana 


\section{ACKNOWLEDGEMENTS}

I wish to extend my sincere thanks to Dr. Richard Latin for his willingness to work with me. I have learned much and enjoyed my time here working with him. Another thanks goes out to my committee members, Dr. Teresa Hughes and Dr. Ron Turco without whom this research would be less than it is. This research could not have been accomplished without the help of Amber Jannasch and Bruce Cooper, who were essential in the mass spectrometry work. To my lab mates over the years I thank you for your help, suggestions, and for the fun times.

To my wife, Jennifer, thank you for your love and for kicking me out the door to get work done when my motivation was lacking. Finally to my family and friends, thank you for your support and love over all the years. 


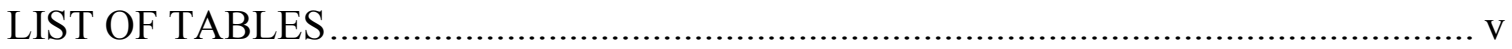

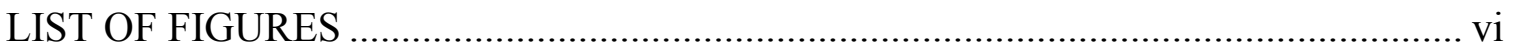

ABSTRACT

CHAPTER 1. LITERATURE REVIEW …........................................................ 1

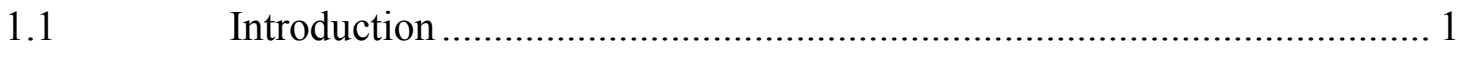

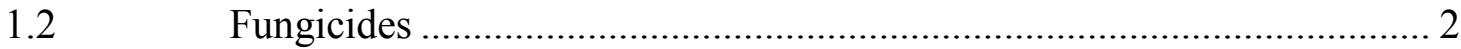

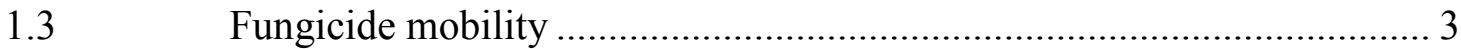

Fungicide persistence in verdure and thatch ................................... 4

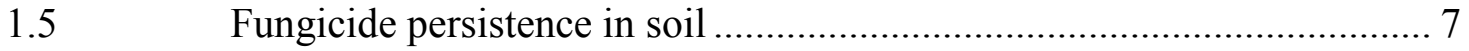

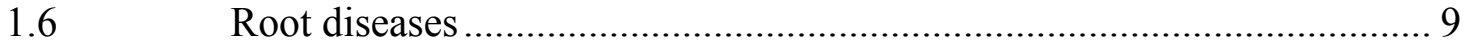

CHAPTER 2. SPATIAL AND TEMPORAL DISTRIBUTION OF FUNGICIDES APPLIED TO CREEPING BENTGRASS ............................................................. 12

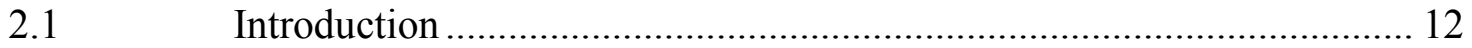

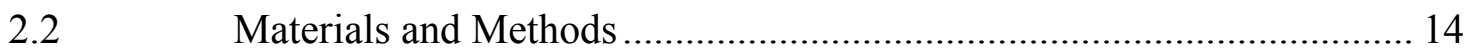

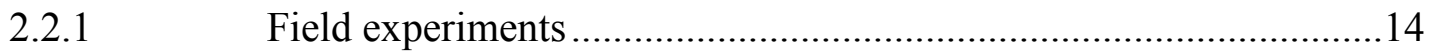

2.2.2 Sample collection and preparation ................................................. 16

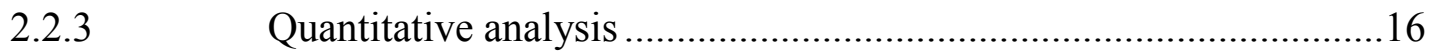

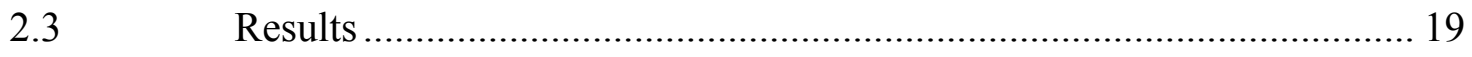

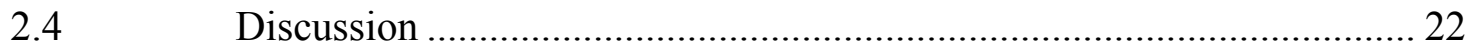

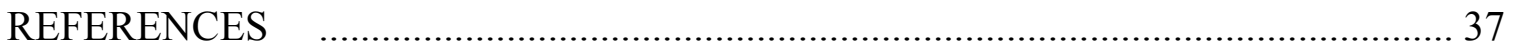




\section{APPENDICES}

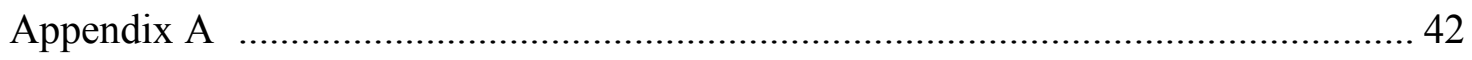

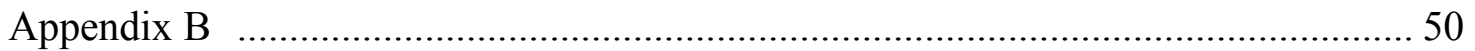

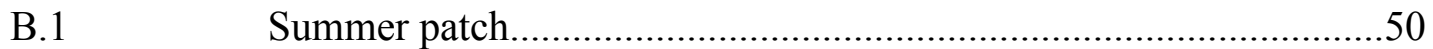

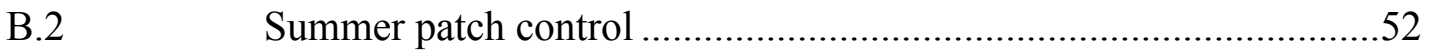

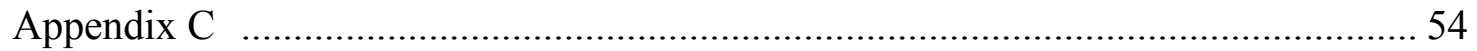

C.1 Intrinsic activity of fungicides against Magnaporthe poae ..............54 


\section{LIST OF TABLES}

Table Page

Table 1. Fungicides applied to creeping bentgrass in 2013 ...................................... 33

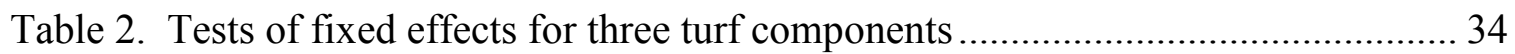

Table 3. First order dissipation half-lives (DHL) of five fungicides applied in July and

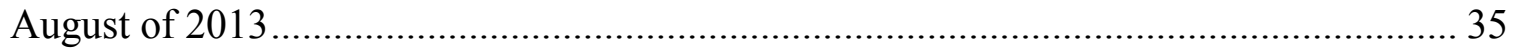

Table 4. Least squares means for the ANOVA model based on roots ........................... 36

Table 5. Least squares means for the ANOVA model based on sand ............................ 36

Table 6. Lease squares means for the ANOVA model based on verdure/thatch............ 36

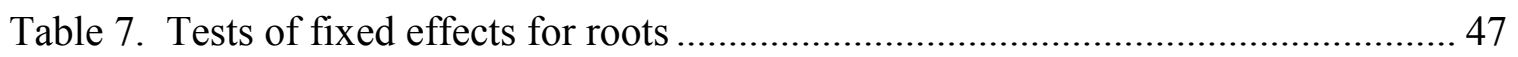

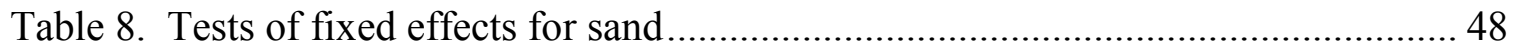

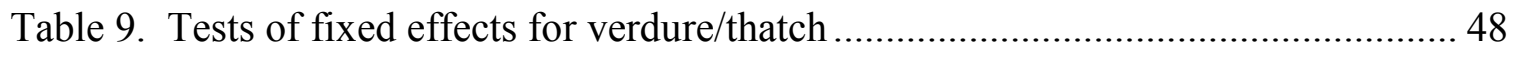

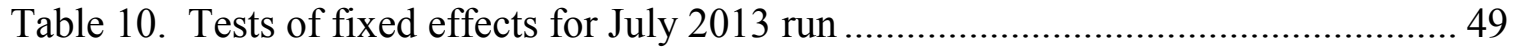

Table 11. Tests of fixed effects for August 2013 run .............................................. 49 


\section{LIST OF FIGURES}

Figure

Page

Figure 1. Spray capture conducted on glass petri plates with theoretical values based on fungicide label rates and actual values obtained using LC-MS/MS 26

Figure 2. Spatial and temporal distribution of thiophanate-methyl on a sand based creeping bentgrass putting green. Experiments were conducted in July 2013 (A) and

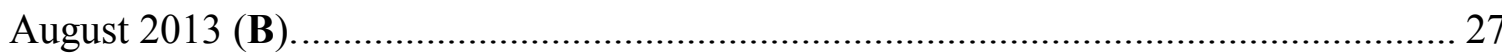

Figure 3. Spatial and temporal distribution of carbendazim on a sand based creeping bentgrass putting green. Experiments were conducted in July 2013 (A) and August 2013

(B). 28

Figure 4. Spatial and temporal distribution of propiconazole on a sand based creeping bentgrass putting green. Experiments were conducted in July 2013 (A) and August 2013

(B).

Figure 5. Spatial and temporal distribution of azoxystrobin on a sand based creeping bentgrass putting green. Experiments were conducted in July 2013 (A) and August 2013

(B). 30 
Figure 6. Spatial and temporal distribution of pyraclostrobin on a sand based creeping bentgrass putting green. Experiments were conducted in July 2013 (A) and August 2013

(B). 31

Figure 7. Percentage of initial azoxystrobin (A) and pyraclostrobin (B) residues detected in each turf component. Experiments were conducted in August 2013. 32

Figure 8. Temporal distribution of four fungicides in creeping bentgrass roots. Preliminary experiment, September 2011 42

Figure 9. Temporal distribution of four fungicides in creeping bentgrass rhizosphere sand. Preliminary experiment, September 2011

Figure 10. Temporal distribution of four fungicides in creeping bentgrass roots.

Preliminary experiment, July 2012

Figure 11. Temporal distribution of four fungicides in creeping bentgrass rhizosphere sand. Preliminary experiment, July 2012.

Figure 12. Temporal distribution of five fungicides in creeping bentgrass roots. Preliminary experiment, August 2012.

Figure 13. Temporal distribution of five fungicides in creeping bentgrass rhizosphere sand. Preliminary experiment, August 2012. 
Figure 14. Percentage of initial azoxystrobin residues detected in each turf component. Experiment was conducted in July 2013.

Figure 15. Percentage of initial pyraclostrobin residues detected in each turf component. Experiment was conducted in July 2013.

Figure 16. Spray capture collected from bottle with theoretical values based on fungicide label rates and actual values obtained using LC-MS/MS 46

Figure 17. Linear regression of relative colony growth data of an isolate of $M$. poae against thiophanate-methyl.

Figure 18. Linear regression of relative colony growth data of an isolate of $M$. poae against propiconazole.

Figure 19. Linear regression of relative colony growth data of an isolate of $M$. poae against azoxystrobin

Figure 20. Linear regression of relative colony growth data of an isolate of $M$. poae against pyraclostrobin. 56 


\begin{abstract}
Hockemeyer, Kurt R. M.S., Purdue University, August 2014. Spatial and temporal distribution of fungicides applied to creeping bentgrass. Major Professor: Richard Latin.

Turf managers often rely on fungicides to limit damage caused by root diseases. Since fungicides do not move basipetally, they are effective only when fungitoxic concentrations are delivered to the rhizosphere (Latin, 2011). This research focused on the distribution of modern fungicides in verdure, thatch, sand, and roots of creeping bentgrass (Agrostis stolonifera L. var. palustris (Huds.) Farw.) maintained as a putting green. Fungicides (azoxystrobin (methyl (E)-2-[2-[6-(2-cyanophenoxy)pyrimidin-4yloxy]phenyl]-3-methoxyacrylate), propiconazole (1,2,4-Triazole, 1-((2-(2,4dichlorophenyl)-4-propyl-1,3-dioxolan-2-yl)methyl), pyraclostrobin (carbamic acid, [2[[[1-(4-chlorophenyl)-1H-pyrazol-3-yl]oxy]methyl $]$ phenyl $]$ methoxy-,methyl ester), and thiophanate-methyl (dimethyl 4,4'-o-phenylenebis[3-thioallophanate]) were applied to replicate field plots in a water volume of $815 \mathrm{~L} \mathrm{ha}^{-1}$. Plots were sampled over time $(0,3$, $7,10,14,17,21$ days after application) by extracting cores measuring $2 \mathrm{~cm}$ diameter by $3.8 \mathrm{~cm}$ deep. Cores were separated into verdure/thatch, sand, and roots before quantitative determination (liquid chromatography, triple quadrupole mass spectrometry) of fungicide residues. Fungicide residues in verdure/thatch declined steadily with time and support previously reported results describing fungicide depletion. Fungicides were
\end{abstract}


detected in roots and sand within 5 hours of application, although at very low (1-15 ppm) concentrations. Residues in roots and sand remained at low levels throughout the experiment. Fungicides differed with respect to amounts recovered per turfgrass component. 


\section{CHAPTER 1. LITERATURE REVIEW}

\subsection{Introduction}

Turfgrasses are affected by numerous infectious diseases, primarily fungal, that result in structural and cosmetic damage. Although there are a variety of nonchemical options often employed to reduce effects of fungal pathogens, synthetic fungicides offer the most effective and consistent solutions to limiting turfgrass disease (Turgeon, 1991). Fungicide persistence in the environment plays an integral role in the performance of that fungicide. Root diseases, including take all patch (caused by Gaeumannomyces graminis (Sacc.) Arx. \& D. Olivier var. avenae (E.M. Turner) Dennis) and summer patch (caused by Magnaporthe poae Landschoot \& Jackson) are particularly difficult to control. At one time, fungicides were thought to move from leaves to roots, where they would suppress existing fungal infections and protect roots from new infections. More recent information on the kinetics of fungicide mobility show that few antifungal compounds have basipetal mobility. Furthermore, none of these basipetal penetrant fungicides are effective against important root diseases of Poa and Agrostis species (Latin, 2011). This review will focus on fungicides and their use for root disease control, and on fungicide mobility and persistence in a turfgrass environment. 


\subsection{Fungicides}

Based on phytomobility, fungicides are classified as either contacts, local penetrants, acropetal penetrants, or systemic penetrants. Contact fungicides were among the first fungicides developed. They are not absorbed into plant tissues but form a protective layer on the outside of leaves and other plant parts. Redistribution may occur from rain, dew, or irrigation water moving fungicide deposits. Contact fungicides typically have multisite modes of action and provide the shortest protection interval (7-14 days). Local penetrants are absorbed into the plant and have an affinity for the waxy cuticle layer located on the outside of the turf leaf blade.

Therefore a fungicide deposit on one side of a leaf will transfer through the leaf blade to the other side of the leaf. This mobility is described as translaminar movement. Acropetal penetrants are xylem mobile fungicides. Xylem is the water conducting tissue of plants and water is taken in through roots and exits from leaves through evapotranspiration. Therefore, these fungicides that are xylem mobile will be upwardly mobile, hence the name acropetal. Systemic penetrants represent fungicides that are truly systemic, moving both up and down the plant. These fungicides follow the carbohydrate gradient in phloem cells. There are few systemic penetrants and they are ineffective against many pathogens.

According to Latin (2011) fungicide performance is based on three factors: use of an effective active ingredient, a fungitoxic concentration of the effective fungicide coming into contact with the pathogen, and adequate persistence in the turfgrass-soil environment. Since effective fungicides are not downwardly mobile, 
and because root pathogens are located in thatch and soil, disease control can only be achieved by ensuring delivery of active ingredients to the rhizosphere where they will act on the active fungal community.

\subsection{Fungicide mobility}

The verdure and thatch layers in a turfgrass sward represent the largest barriers to delivery of fungicides to the rhizosphere. Thatch is a strongly intermixed layer of living and dead stems, leaves, and roots of grass that occurs naturally between the verdure and soil surface (Hurto et al., 1980). Much research has been conducted on the mobility of fungicides and other pesticides in a turfgrass system in the context of environmental fate. Schumann et al. (2000) tested three different fungicide delivery systems for their ability to transfer active ingredients below verdure and thatch to roots. They were not able to detect fungicides in roots in any appreciable amount and no fungicides were detected below $5.1 \mathrm{~cm}$ of soil. Wu et al. (2002) investigated two fungicides, chlorothalonil and metalaxyl, for their mobility in a putting green in southern California. Residues were mainly detected in the upper $10 \mathrm{~cm}$ of soil. They attributed these results to the high organic carbon content found in thatch. Another study directly compared mobility of cyproconazole in bare soil and in turf containing different levels of thatch (Gardner et al., 2000). This study indicated that increasing the amount of thatch decreased the amount of cyproconazole that reached soil. Even when $67 \%$ of thatch was removed, no cyproconazole residues were detected below $5 \mathrm{~cm}$. A similar study by Gardner and Branham (2001) evaluated turfgrass cover and irrigation regime on the mobility of mefenoxam and 
propiconazole. The presence of turfgrass cover drastically reduced the movement of fungicide residues into the soil. Dell et al. (1994) conducted sorption studies for triadimefon, vinclozolin, and chloroneb in thatch and soil. They were able to show that thatch drastically increased the sorption of fungicides. The increased sorption correlates to a lower potential for fungicides in turf to migrate off site. Horst et al. (1996) evaluated four pesticides for their mobility in a Kentucky bluegrass fairway.

Thatch typically contained the highest amount of residues detected while soil held on average $58 \%$ less residues on all sampling days. A majority of soil residues were detected in the top $10 \mathrm{~cm}$. Frederick et al. (1996) were also able to show that very little vinclozolin residues infiltrated below verdure and thatch and no residues were detected below $4 \mathrm{~cm}$. The consensus of these studies is that turfgrass cover (verdure and thatch) intercepts and retains a large portion of pesticide residues and allows very little residues to infiltrate into soil. Once fungicides are applied to turf, they are subject to a myriad of dissipation processes that affect persistence.

\subsection{Fungicide persistence in verdure and thatch}

The third factor in determining fungicide performance is persistence in the environment (Latin, 2011). As discussed in the previous section, verdure and thatch are capable of significantly reducing the amount of pesticides that reach the roots and soil and therefore persistence in these components is important in determining fungicide performance against root diseases. Daniels and Latin (2013) evaluated the residual efficacy of fungicides against brown patch by bioassay and quantitative analysis. The bioassay revealed a rapid decline in residual efficacy within 10 days of 
application. Quantitative analysis of residues in verdure reinforced bioassay results by revealing very rapid dissipation of residues. Reported half-lives in verdure were 1.0, 2.2, 1.6, and 2.4 days for azoxystrobin, flutolanil, metconazole, and pyraclostrobin, respectively. Sigler et al. (2003) evaluated dissipation of three fungicides from verdure. Reported half-lives of triadimefon, metalaxyl, and iprodione were 3.3, 3.7, and 3.6 days, respectively. Horst et al. (1996) reported the half-lives of metalaxyl, pendimethalin, chlorpyrifos, and isazofos in a Kentucky bluegrass fairway to be $16,12,10$, and 7 days, respectively. These values are lower than half-lives of these pesticides in agricultural soils. The half-lives of three fungicides in bare soil versus a bentgrass turf were evaluated by Gardner et al. (2000) and Gardner and Branham (2001). Cyproconazole, propiconazole, and mefenoxam had half-lives of 129, 29, and 7-8 days in bare soil, respectively. The addition of turf cover decreased these values to $12,12-15$, and 5-6 days. Half-lives of metalaxyl and chlorothalonil have been reported as 2.7 and 5.6 days in thatch and 1.4 and 4.9 days in verdure (Wu et al., 2002). Liu and Hsiang (1996) monitored the in vitro degradation of carbendazim in thatch using a bioassay and estimated half-life at 17.5 days. The degradation rates of two herbicides were significantly faster in Kentucky bluegrass thatch than in soil (Hurto et al., 1979). These studies support the idea of faster degradation in turf than in soil. Conversely some research supports the concept of faster degradation in soil.

According to Magri and Haith (2009) pesticide degradation due to microbial activity in thatch is expected to be higher than in agricultural soils. This is due to highly active microbial populations and repeated applications of pesticides to turf. 
Repeated applications of pesticides have been studied in soils, and the enhanced biodegradation phenomenon has often been observed (Chapman et al., 1986; Slade et al., 1992; Walker et al., 1986). The theory behind enhanced biodegradation is that microbes that are able to degrade the pesticide being applied become a much larger part of the population with each repeated application, therefore persistence decreases with each application. Frederick et al. (1996) determined that a rapid decline in vinclozolin residues in verdure and thatch after repeated applications was due to enhanced biodegradation. Conversely, Sigler et al. (2003) refuted their own hypothesis that repeated applications would result in enhanced biodegradation in the verdure. Sigler et al. (2000) stated that microbial degradation in the canopy is slower than in soil due to the inhospitable microbial environment. The canopy is exposed to high amounts of UV light and extreme changes in free water which are not conducive to high microbial activity. Another study reveals slower dissipation values in thatch and grass clippings than in soil for chloroneb, triadimefon, and vinclozolin (Frederick et al., 1994).

Daniels and Latin (2013) reported very rapid dissipation of fungicides in verdure alone. Residue half-lives were 1.0, 2.4, 2.2, and 1.6 days for azoxystrobin, pyraclostrobin, metconazole, and flutolanil, respectively. Sigler et al. (2003) reported that even though large numbers of microorganisms populate the turf leaf surface ( $\sim 10^{8} \mathrm{~g}^{-1} \mathrm{dr}$ wt leaf), microbial degradation plays a less important role in the fungicide's fate. Instead they concluded that a two-stage physical sorption process is the major reaction pathway that controls the fate of fungicides. Sigler et al. (2003) reported half-lives in the turfgrass canopy for triadimefon, metalaxyl, and iprodione 
as $3.3,3.7$, and 3.6 days, respectively. These rapid dissipation values are comparable to the values reported by Daniels and Latin (2013) and suggest rapid microbial degradation. Their work showed little microbial mineralization of ${ }^{14} \mathrm{C}$-labeled fungicides, only 1-2\%. Instead they were able to show that after 24 hours 97,65 , and $80 \%$ of applied metalaxyl, triadimefon, and vinclozolin became unextractable from the leaf surface. Rapid verdure dissipation is more likely a result of many dissipation processes working in unison to remove or degrade residues of pesticides, including microbial degradation, leaf surface partitioning, clipping removal, photolysis, volatilization, etc.

\subsection{Fungicide persistence in soil}

Persistence of fungicides in soil is important in determining fungicide fate. Fungicide persistence has been studied in agricultural and turf soils. Singh and Dureja (2009) investigated the effect of biocompost soil amendment on the degradation of penconazole and propiconazole. Half-lives were 41.2 and 73.4 days for penconazole and propiconazole, respectively. Flooding soils increased half-lives to 57.9 and 91.2 days. Mixing biocompost at 5\% with soil increased degradation and decreased half-lives to 30.1 and 51.9 days. The dissipation of azoxystrobin, a relatively new fungicide, has been monitored in a sandy loam soil (Ghosh and Singh, 2009). Azoxystrobin dissipated faster under anaerobic conditions, with reported halflives of 107 and 63 days for aerobic and anaerobic conditions, respectively. Amending soil with compost enhanced degradation to half-lives of 73 and 39 days. Azoxystrobin also degraded through photolysis, but photolysis degradation was faster 
in ultraviolet light than in sunlight. They determined that soil serves as a screen and protects azoxystrobin from photolysis. The effects of different soil characteristics on the degradation of another relatively new fungicide, pyraclostrobin, have been studied (Reddy et al., 2013). Like azoxystrobin, pyraclostrobin dissipation is faster under anaerobic conditions (10 days vs 28.7 days). Sludge amended soil resulted in faster dissipation of pyraclostrobin with a half-life of 9.2 days. Thom et al. (1997) investigated the dissipation of difenoconazole in soils. Adding an organic amendment to soil increased dissipation, with half-life values dropping from 46 days to 15 days. Thiophanate-methyl has been shown to dissipate very quickly in soils (Fleeker et al., 1974). Five days after an application $80-90 \%$ of thiophanate-methyl residues had dissipated. Thiophanate-methyl degrades mainly into one metabolite, carbendazim. This metabolite has fungicidal properties and is the main reason why thiophanate-methyl is used as a fungicide. Carbendazim half-life was reported as 28 days in soil, slower than in thatch (Liu and Hsiang, 1994). Frederick et al. (1994) determined that lab incubations of turf soil, thatch, and grass clippings resulted in fastest dissipation occurring in soil. Gardner et al. (2000) and Gardner and Branham (2001) directly compared bare soil and turf cover dissipation values and found that bare soil half-lives were higher than turf half-lives. These studies generally show that soil dissipation values are slower and adding organic matter to soils increases dissipation rates. Turf thatch and soils are generally very high in organic matter and perhaps this explains why dissipation is faster in a turf environment. 


\section{$1.6 \underline{\text { Root diseases }}$}

Prior to 1984 there was only one member of the ectotrophic root-infecting fungi group that was recognized as a pathogen of turfgrass in North America. Since then there have been a number of advancements of knowledge within this group (Clarke and Gould, 1993). Today there are five disease associations within this group. Take-all patch of creeping bentgrass caused by the pathogen Gaeumannomyces graminis var. avenae was the first member of this group. This pathogen affects many grass species but bentgrasses are the most susceptible. Spring dead spot of bermudagrass is caused by the pathogens Ophiosphaerella korrae and $O$. herpotricha. Bermudagrass decline is caused by the pathogen Gaeumannomyces graminis var. graminis. Necrotic ring spot is caused by the pathogen Leptosphaeria korrae and affects bluegrass species. It was originally described as Fusarium blight, but after decades of research it became apparent that a combination of diseases had been placed under the name Fusarium blight. Summer patch was the second disease that was segregated from the Fusarium blight misnomer. Summer patch is caused by the pathogen Magnaporthe poae and is another serious disease of bluegrasses and fine fescues (Smiley, 1993). These diseases are difficult to control and among the most destructive because of the limited availability of disease resistant germplasm, poor understanding of pathogen biology, lack of field studies that examine the effects of cultural practices on disease severity, and inconsistent control with fungicides (Dernoeden, 1993) 
Management of root diseases with fungicides is a very common practice because of the low tolerance for damage on turf playing surfaces. But much of the research available on fungicidal control of root diseases is contradictory. Gregos and Jung (2003) found the active ingredients pyraclostrobin and azoxystrobin provided excellent control of take-all patch in colonial bentgrass, triadimefon provided acceptable control, and propiconazole treatments were not acceptable. This study suggests that strobilurin fungicides, azoxystrobin and pyraclostrobin, provide excellent control of take-all patch, despite these two fungicides having differing phytomobilities. Their results also suggest that DMI fungicides, triadimefon and propiconazole, are not as efficacious for take-all patch control. In a later study for curative control of take-all patch, McDonald et al. (2007) reported that control was best achieved with applications of azoxystrobin, tebuconazole, or a combination product of azoxystrobin and propiconazole. Pyraclostrobin treatments still showed damage after most other treatments were completely void of symptoms. This study contradicts the other by showing that a DMI can provide excellent control of this root disease and that pyraclostrobin did not provide excellent control. The first study was a preventative study while the second was a post outbreak study and this difference may have accounted for discrepancies in control. From 1999 to 2011 seven studies from Plant Disease Management Reports and Fungicide \& Nematicide Tests evaluated fungicide applications for their efficacy against summer patch (Earlywine and Miller, 2012; Majumdar et al., 2000; Mitkowski and Boesch, 2006; Soika and Tredway, 2010a; Soika and Tredway, 2010b; Vincelli et al., 2004; Wong and Corza, 2005). In these seven studies, four described azoxystrobin as providing acceptable 
control while one showed azoxystrobin treatments were not significantly better than no fungicide check treatments. Two studies described their pyraclostrobin treatments or treatments in combination with pyraclostrobin as providing excellent control. One study indicated that pyraclostrobin improved turf quality slightly while another showed unacceptable control of summer patch. Three studies resulted in propiconazole providing the best control or one of the best. One study evaluated propiconazole as providing less control. Two studies described thiophanate-methyl as offering good to excellent suppression of summer patch symptoms, while two other studies showed thiophanate-methyl provided some but not acceptable control. These are just a few examples of studies evaluating fungicidal control of root diseases and the discrepancies found therein. There are many differences among these seven studies including application volume, application interval, fungicides evaluated, evaluation criteria, first application date, etc. These many differences complicate the task of directly comparing results. The point of this discussion is to highlight the inconsistencies observed when attempting to control root diseases with fungicides.

When considering the barriers to delivering fungicides to the turf rhizosphere and the rapid dissipation that occurs in a turf environment, it is not surprising that results of fungicide applications can be so inconsistent. To better understand these inconsistencies, a determination of the spatial distribution of fungicides on high value turf must be conducted, including roots of turfgrass. Observing the dissipation of these fungicides over time may also help in understanding control of root diseases with antifungal compounds. 


\section{CHAPTER 2. SPATIAL AND TEMPORAL DISTRIBUTION OF FUNGICIDES APPLIED TO CREEPING BENTGRASS}

\subsection{Introduction}

Root diseases such as take all patch (caused by Gaeumannomyces graminis (Sacc.) Arx. \& D. Olivier var. avenae (E.M. Turner) Dennis) and summer patch (caused by Magnaporthe poae Landschoot \& Jackson) cause serious cosmetic and structural damage to intensively managed turf on golf courses. Compared to healthy roots, those impaired by infection are less able to sustain plant growth under periods of heat and drought stress - common occurrences in the Midwestern United States. Golf course superintendents often employ a variety of stress-relieving cultural practices in order to mitigate effects of disease (Dernoeden, 1993). However, because of extremely low damage tolerance on fine turf, they often rely on fungicides to limit infection and reduce the likelihood of unacceptable damage to playing surfaces.

Although numerous antifungal compounds are registered for use on turfgrass against root diseases, fungicide application does not assure successful disease control (Latin, 2011). Fungicides are applied to the verdure - green leaves and stems — while root pathogens inhabit the thatch and rhizosphere. Furthermore, compounds effective against root pathogens are xylem-mobile or translaminar, and therefore, are not transported to roots through the plant. Instead, they must move below the verdure in order to intercept 
pathogen growth in and around plant roots. Delivery of effective compounds into thatch and rhizosphere is usually facilitated by supplemental irrigation following the application, and/or increasing the water carrier volume of the application. Based on the archive published in Plant Disease Management Reports, chemical control of root diseases such as summer patch and take-all patch remains inconsistent, despite applying effective fungicides accompanied by a variety of efforts to improve the likelihood of success.

Understanding the spatial and temporal distribution of fungicides in creeping bentgrass turfgrass may help explain inconsistencies in fungicide performance against root diseases. Early research was conducted in the context of environmental fate of pesticides, including fungicides. Thom et al. (1997) examined the effects of pretreatment and organic amendment on the degradation of difenoconazole. Horst et al. (1996) monitored the vertical movement and dissipation of pendimethalin, chlorpyrifos, isazofos, and metalaxyl. Sorption studies were conducted for the fungicides triadimefon, vinclozolin, and chloroneb in thatch and soil (Dell et al., 1994). Frederick et al. (1994) observed the degradation of chloroneb, triadimefon, and vinclozolin in soil, thatch, and grass clippings under laboratory conditions. Gardner et al. (2000) directly compared the effects of varying levels of turfgrass cover on the dissipation and mobility of cyproconazole. Gardner and Branham (2001) studied the effects of turfgrass cover and irrigation regime on the mobility and dissipation of mefenoxam and propiconazole. Liu and Hsiang (1996) estimated degradation of benzimidazole residues in thatch and turfgrass clippings by bioassay. Wu et al. (2002) evaluated chlorothalonil and metalaxyl 
for their persistence and fate in a bentgrass putting green. Schumann et al. (2000) conducted a study on fungicide delivery to control root diseases. They compared new delivery systems for their ability to transfer fungicides below thatch and into roots. For all of the aforementioned published reports, results and conclusions support the concept of a rapid decline in residues in the verdure, almost no accumulation in the soil and roots, and a significant accumulation in thatch. Daniels and Latin (2013) were among the first to explore fungicide dissipation in terms of potential for foliar disease control. They used a bioassay as well as a quantitative approach to correlate reductions in fungicide residue with fungicide performance against brown patch, a foliar disease of amenity turf such as creeping bentgrass.

The research reported here focused on different components (verdure/thatch, roots, and sand substrate) of bentgrass turf, and examined distribution of modern fungicides. The objective was to investigate where fungicides (especially modern fungicides) accumulated and how long they remained on site.

\subsection{Materials and Methods}

\subsubsection{Field experiments}

Field plots were located on a sward of a mature mixture of 'Penncross' and 'Backspin' creeping bentgrass on a sand based rootzone at the William H. Daniel Turfgrass Research and Diagnostic Center in West Lafayette, IN. Experiments to refine sampling and extraction techniques were conducted in 2011 and 2012 (Figures 8-13). Two comprehensive runs of the experiment were completed during summer 2013. 
Maintenance practices for this site were standard for a creeping bentgrass putting green in the Midwest. The site was mowed with a triplex reel mower 5 days per week at a height of $0.343 \mathrm{~cm}$ with the clippings collected. Irrigation was applied in a supplemental manner to avoid drought stress. Fertilizer was applied to provide $147 \mathrm{~kg}$ nitrogen $\mathrm{ha}^{-1} \mathrm{yr}^{-}$ 1, $27 \mathrm{~kg}$ phosphorous ha $\mathrm{yr}^{-1}$, and $68 \mathrm{~kg}$ potassium $\mathrm{ha}^{-1} \mathrm{yr}^{-1}$. Aerification was performed once in the spring and once in the fall using $1.27 \mathrm{~cm}$ hollow tines at $5 \times 5 \mathrm{~cm}$ spacing. After aerification, the greens were verticut twice and topdressed with sand. Prior to the application of experimental treatments, boscalid (3-pyridinecarboxamide, 2-chloro-N-(4'chloro(1,1'-biphenyl)-2-yl) (Emerald; BASF Corporation, Research Triangle Park, NC) and/or chlorothalonil (tetrachloroisophthalonitrile) (Daconil Ultrex; Syngenta Crop Protection, Greensboro, NC) were applied to the field site to suppress infection by Sclerotinia homeocarpa F.T. Bennett and avoid turf damage associated with disease. Boscalid and chlorothalonil are not related to compounds investigated in this research.

Fungicides selected for use in this research included azoxystrobin (Heritage TL; Syngenta Crop Protection, Greensboro, NC), propiconazole (Banner Maxx; Syngenta Crop Protection, Greensboro, NC), thiophanate methyl (3336F; Cleary Chemical Corporation, Dayton, NJ), and pyraclostrobin (Insignia SC; BASF Corporation, Research Triangle Park, NC). They were applied at high label rates (Table 1) with a custom built $\mathrm{CO}_{2}$ pressurized boom sprayer using three air induction nozzles with flat fan tips (TeeJet Technologies, Wheaton, IL). Nozzles were spaced $38 \mathrm{~cm}$ apart and $41 \mathrm{~cm}$ above the turf surface. The application volume was equivalent to 815 liters ha $^{-1}$ at 35 psi. All fungicides were tank mixed and applied as a single treatment to four replicate plots each measuring $1 \mathrm{~m}$ by $2 \mathrm{~m}$. Turfgrass was irrigated for approximately five minutes 
immediately after fungicide application. Total water volume applied through irrigation ranged between $0.33-0.38 \mathrm{~cm}$.

\subsubsection{Sample collection and preparation}

Samples were collected using a $1.9 \mathrm{~cm}$ soil probe to a depth of $3.8 \mathrm{~cm}$ at $0,3,7$, $10,14,17$, and 21 days after fungicide application from the treated turfgrass. Residues were determined in turfgrass roots, rhizosphere sand, and in the combined verdure/thatch. Prior to the application of fungicide treatments, plots were sampled to establish a baseline of residues in the experimental site. For each core sample the verdure/thatch component was immediately separated from the roots and sand and placed in an individual $50 \mathrm{~mL}$ polypropylene tube. Samples were placed in a $-80{ }^{\circ} \mathrm{C}$ freezer and stored until fungicide extraction. Root and sand samples were dried (Yamato DKN600 Mechanical Convection Oven, Santa Clara, CA) at $43^{\circ} \mathrm{C}$ for 24 hours. Once dry, root and sand components were separated using a No. 14 (1.4 mm) USA Standard Test Sieve and placed into $50 \mathrm{~mL}$ polypropylene centrifuge tubes and stored at $-80{ }^{\circ} \mathrm{C}$ until extraction.

\subsubsection{Quantitative analysis}

Residues were measured using liquid chromatography-mass spectrometry/mass spectrometry (LC-MS/MS). In addition to the four fungicides analyzed, the metabolite of thiophanate-methyl, methyl 2-benzimidazole carbamate (MBC or carbendazim) was also analyzed because thiophanate-methyl is rapidly degraded into this fungitoxic metabolite (Fleeker et al., 1974). Analytical standards for all fungicides—azoxystrobin (99.4\%), pyraclostrobin (99.9\%), propiconazole (99.2\%), thiophanate methyl (99.3\%), carbendazim (99.2\%), and metconazole (99.5\%) -were obtained from Sigma-Aldrich (St. 
Louis, MO). Stock solutions of $10 \mathrm{mg} / \mathrm{ml}$ were prepared in pure acetonitrile for all standards except carbendazim, which was prepared in pure acetone at $0.3 \mathrm{mg} / \mathrm{ml}$. Stock solutions were stored in microcentrifuge tubes at $-20^{\circ} \mathrm{C}$. HPLC-grade acetone and acetonitrile along with reagent grade magnesium sulfate and sodium acetate were obtained from Sigma-Aldrich. Dispersive solid phase extraction (d-SPE) tubes (15 mL) were obtained from Agilent Technologies (Santa Clara, CA). Verdure/thatch and root samples were homogenized using an Ultra-Turrax T8 from IKA (Wilmington, NC). Fungicide extraction was based on the QuEChERS method developed by Anastassiades et al. (2003) with modifications from Daniels and Latin (2013). Samples were weighed before extraction. Verdure/thatch and root extraction consisted of adding $15 \mathrm{~mL}$ of 80/20 $\mathrm{v} / \mathrm{v}$ acetonitrile/water to each tube. All samples were spiked with $10 \mu \mathrm{L}$ of metconazole $(10 \mathrm{mg} / \mathrm{mL})$ internal standard for quality assurance, and then homogenized for a uniform extract. Magnesium sulfate $(400 \mathrm{mg})$ and sodium acetate $(100 \mathrm{mg})$ were added to each tube and shaken vigorously for 1 minute before centrifuging at $3000 \mathrm{rpm}$ for 5 minutes. An $8 \mathrm{~mL}$ aliquot was removed from the top phase of the extract and transferred to a 15 $\mathrm{mL}$ d-SPE tube containing $855 \mathrm{mg}$ anhydrous magnesium sulfate, $150 \mathrm{mg}$ PSA, and 45 mg GCB and shaken vigorously for 1 minute before centrifuging at $3000 \mathrm{rpm}$ for $5 \mathrm{~min}$. Supernatant $(1 \mathrm{~mL})$ was then transferred to an Eppendorf tube and stored at $-20{ }^{\circ} \mathrm{C}$ until analysis. Extract $(200 \mu \mathrm{L})$ was transferred into an autosampler vial and placed in the autosampler plate for analysis by the LC-MS/MS. Sand samples followed a simplified extraction protocol proposed by Pinto et al. (2010). The simplified approach does not involve homogenization, does not add sodium acetate, and does not contain the d-SPE step. Fungicide residues were detected using an Agilent 1200 series Rapid Resolution 
liquid chromatography system consisting of a vacuum degasser, a well-plate autosampler, and a binary pumping device coupled to an Agilent 6460 Triple Quad (QQQ) mass spectrometer (Agilent Technologies). The column used for separation of fungicides was a reversed-phase Zorbax SB-Phenyl column $(4.6 \mathrm{~mm}$ x $150 \mathrm{~mm}, 5 \mathrm{um})$ also from Agilent. Mobile phases were as follows: solvent A contained 20/80 v/v methanol/water and solvent B contained $90 / 10 \mathrm{v} / \mathrm{v}$ acetonitrile/water, with both solvents containing $5 \mathrm{mM}$ ammonium acetate $(\mathrm{pH}=5)$. The gradient was the following: time 0 minutes, $50 \% \mathrm{~B}$; time 1 minute, $50 \% \mathrm{~B}$; time 5 minutes, $100 \% \mathrm{~B}$; time 10 minutes, $100 \% \mathrm{~B}$; time 11 minutes, $50 \% \mathrm{~B}$; time 15 minutes, $50 \% \mathrm{~B}$. The flow of the mobile phases was $0.8 \mathrm{ml}$ $\min ^{-1}$, and the column was held at room temperature. Injection volume was $10 \mu 1$ for all standards and sample extracts. Mass spectrometry analysis used positive polarity electrospray ionization with the following source parameters: capillary voltage, $3500 \mathrm{~V}$; nozzle voltage, $1000 \mathrm{~V}$; nebulizer pressure, $310 \mathrm{kPa}$; drying gas, $8 \mathrm{~L} \mathrm{~min}^{-1}$; gas temperature, $325^{\circ} \mathrm{C}$; sheath gas, $10 \mathrm{~L} \mathrm{~min}^{-1}$; sheath gas temperature, $250{ }^{\circ} \mathrm{C}$. Data were acquired using multiple reaction mode (MRM) with a dwell time of $50 \mathrm{~ms}$ and unit resolution. Samples were evaluated with Agilent MassHunter Quantitative Analysis (version B01.04) software to determine residue concentrations. Efficiencies of recovery for thiophanate-methyl, azoxystrobin, propiconazole, and pyraclostrobin were 67.4, 88.9, 85.8 , and $86.1 \%$, respectively (Figure 1 ).

Residue data were normalized per gram of component sampled and subjected to analysis of variance (SAS, v 9.2, PROC MIXED) to explore differences in fungicide depletion over time. Dissipation half-lives (DHL) were calculated where applicable 
using a first order decay model $\left(\mathrm{t}_{1 / 2}=\ln (2) / \mathrm{k}\right)$. DHL means were separated using analysis of variance (SAS, v 9.2, PROC GLM).

\section{$2.3 \underline{\text { Results }}$}

Significant differences in fungicide concentrations were observed across all turfgrass components (verdure/thatch, roots, and sand) for "fungicide" and "sampling date" effects (Table 2). The nature of differences in measurable residues for replication and run varied among components. Within the sand component, all factors and interactions were statistically different $(\mathrm{P}=0.05)$. Similar results were observed within the verdure/thatch component, except that differences among replications were not significant $(\mathrm{P}=0.05)$. For root samples, only fungicide effects, sampling date effects, and the fungicide*sampling date interaction were statistically significant. Although spatial and temporal distributions for all fungicides were similar over both runs of the experiment, significant run effects were identified in the analysis of variance. Therefore, characteristics of fungicide depletion will be addressed separately as appropriate for each run.

DHL values show similar results for fungicides in each turfgrass component in both runs of the experiment (Table 3). For example, DHL values for all fungicides were similar in the sand component. Near zero quantities of azoxystrobin, propiconazole and pyraclostrobin over all sampling dates precluded calculation of DHL for those fungicides in sand. Only thiophanate-methyl and the carbendazim metabolite were detected to the extent that DHL was determined - and they were similar for both runs. DHL for thiophanate-methyl in sand in runs 1 and 2 were 2.8 and 2.9 days, respectively. For 
carbendazim in sand, DHL was 7.0 and 9.3 days, for runs 1 and 2, respectively. Within the root component, DHL values for propiconazole were greatest (14.5 and 24.4 days in runs 1 and 2, respectively). DHL for azoxystrobin in roots were similar between runs (12.7 days and 10.1 days for runs 1 and 2, respectively). Pyraclostrobin does not accumulate in roots (it is not xylem-mobile) and therefore DHL could not be calculated. In the verdure/thatch component, greatest DHL was associated with pyraclostrobin (18.9 and 13.5 days for runs 1 and 2 , respectively).

Comprehensive illustrations of dissipation for all fungicides in turfgrass components are presented in Figures 2-6. Baseline samples collected prior to application of fungicide treatments resulted in no detectable residues of active ingredients used in this research. Measurable amounts of all fungicides were present in all sample components (verdure/thatch, roots, sand) within five hours of the application (sample day 0). Fungicides differed with regard to their distribution in various components.

Depletion of thiophanate-methyl was similar in both runs of the experiment (Figure 2, A and B). Greatest amounts were observed in verdure/thatch shortly after application and were depleted over the next seven days. Lesser amounts were observed in roots and were almost totally depleted seven days after application. Thiophanate-methyl was barely detectable in the sand component for all sampling dates. Thiophanate-methyl degraded into its main fungitoxic metabolite, carbendazim (Figure 3, A and B). Carbendazim levels were lower in the verdure/thatch component compared to roots, and near zero levels were observed in sand. Regardless of turfgrass component, for both runs of the experiment, carbendazim residues approached zero 14 days after application. 
Propiconazole depleted in verdure/thatch over time, but did not approach zero until 21 days after application. (Figure 4, A and B). As fungicide dissipated in verdure/thatch, it accumulated in roots. Of all fungicides applied, propiconazole was observed in greater amounts (20-25 ppm) in roots 21 days after the application. Near zero levels were measured in sand. Results were similar in both runs of the experiment.

Marked differences in spatial and temporal distribution were observed between the two QoI fungicides, azoxystrobin and pyraclostrobin. Azoxystrobin was detected at higher levels in roots versus verdure/thatch on almost all sampling dates (Figure 5, A and B). Conversely, greater amounts of pyraclostrobin were measured in the verdure/thatch component compared to roots on all sampling dates (Figure 6, A and B). Root residues were significantly higher for azoxystrobin, ranging from 4-12 $\mu \mathrm{g} \mathrm{g}^{-1}$ roots, while pyraclostrobin was only detected between $0.5-1.8 \mu \mathrm{g} \mathrm{g}^{-1}$ roots. Azoxystrobin resulted in an initial period of uptake in roots followed by slow dissipation (DHL ranged between 10 and 13 days for runs 1 and 2, respectively). Pyraclostrobin root residues were initially low $\left(>1 \mu \mathrm{g} \mathrm{g}^{-1}\right)$ and remained near zero throughout the sampling period. Analysis of variance of fungicide residues in roots over all sampling dates and both runs showed that pyraclostrobin residues were not significantly different $(\mathrm{P}=0.1518)$ from zero on all sampling dates (Table 4). Using the Tukey multiple comparison method (Hsu, 1996) significant differences between azoxystrobin and pyraclostrobin were identified at the $\mathrm{P}=0.0001$ probability level in roots (least squares estimates of $7.2277 \mathrm{vs} 1.0451 \mu \mathrm{g} \mathrm{g}^{-1}$ for azoxystrobin and pyraclostrobin, respectively) (Table 4). Statistical differences also were identified in the sand component (least squares estimates of 0.4002 vs $0.1060 \mu \mathrm{g} \mathrm{g}^{-1}$ for azoxystrobin and pyraclostrobin, respectively) (Table 5), but not in the verdure/thatch 
component (2.9473 vs $4.5705 \mu \mathrm{g} \mathrm{g}^{-1}$ for azoxystrobin and pyraclostrobin, respectively) (Table 6).

\subsection{Discussion}

This research describes differences and similarities in the dissipation of fungicides applied to creeping bentgrass. Prior to this work we find few direct comparisons that can be made to previous published reports. Liu and Hsiang (1996) estimated in vitro degradation of carbendazim in thatch to be 2.5 weeks (17.5 days) which differs from our estimation of field degradation of carbendazim (5.4-5.6 days). Quantification of residues was conducted using a thatch-agar pellet bioassay and spectrophotometry. Because their study estimated in vitro degradation, factors such as fluctuating temperatures and moisture levels, photolysis, root uptake, etc., were not contributing to dissipation and may account for such differences in half-lives.

Gardner and Branham (2001) investigated the fate of propiconazole in a turfgrass environment. They reported a half-life for propiconazole in turfgrass to be 12-15 days and in bare soil 29 days. Our reported DHL values were 6-10 days in verdure/thatch and 14-24 days in roots, shorter times than their reported half-life. They estimated DHL by log transforming residues detected and regressing transformed values over time. It is possible that the calculation difference contributed to the slight variation in DHL values. There were also differences in sample collection, extraction procedure, as well as liquid chromatograph and mass spectrometer analysis parameters. Their results are similar to ours in that they report very high residue amounts in verdure and thatch and little residual chemical in the underlying soil. On day 21 our data show relatively high propiconazole 
residues in roots. This is surprising considering rapid decline in efficacy against brown patch and dollar spot reported in bioassay experiments by Daniels and Latin (2013) and Latin (2006). Schumann et al. (2000) reported almost no fungicide reaching roots. Although they investigated fungicide residues in roots, experiments were conducted on a Kentucky bluegrass sward with a thatch layer 5 times thicker than what was observed on our experimental putting green.

In this research approximately 6-8 $\mu \mathrm{g} \mathrm{g}^{-1}$ of azoxystrobin and pyraclostrobin were observed on day 0 in verdure/thatch (Figures 5 and 6), much lower than what was reported by Daniels and Latin (127 and $200 \mu \mathrm{g} \mathrm{g}^{-1}$ verdure) (2013). The addition of the thatch layer in this study most likely explains why there is a large discrepancy. Thatch comprised a majority of the mass of each verdure/thatch sample. If verdure alone would have been analyzed, it would require greater amounts of turf foliage to obtain one gram, and therefore residues detected also would be greater. In addition, irrigation in this study may have washed residues off verdure and below thatch which could also help explain this discrepancy.

Results of our research generally show lower residue levels in the turfgrass system compared to previously published reports. We normalized residue amounts per gram of component analyzed, following the precedent of Daniels and Latin (2013), Frederick et al. (1994), and Wu et al. (2002). Horst et al. (1996) reported their results as total chemical residues detected. Schumann et al. (2000) reported percent of applied fungicide. Gardner et al. (2000) and Gardner and Branham (2001) expressed results in normalized and untransformed terms. These differences in reporting may account for differences in the reported residues detected. In our work, the average component 
weights recovered were $0.3589 \mathrm{~g}$ roots core $^{-1}, 10.9912 \mathrm{~g}$ sand core ${ }^{-1}$, and $1.1516 \mathrm{~g}$ verdure/thatch core ${ }^{-1}$. After normalization root residues were generally higher than sand residues because of the low weight of the root component. Sand residues never accumulated above $1.5 \mu \mathrm{g} \mathrm{g}^{-1}$ because of the high weight of sand component recovered and residues remained low throughout the study.

The dissipation of azoxystrobin and pyraclostrobin has been investigated in agricultural soils. Ghosh and Singh (2009) reported on the degradation and sorption of azoxystrobin in a sandy loam soil. The dissipation of pyraclostrobin in soils has also been explored (Reddy et al., 2013). To our knowledge this paper is the first to describe dissipation of these more modern QoI fungicides for turfgrass. They have similar modes of action, but differ in terms of phytomobility—azoxystrobin is an acropetal penetrant (xylem mobile) and pyraclostrobin is a local penetrant (translaminar) (Latin, 2011). This research describes differences in distribution of these fungicides in turf. For azoxystrobin and pyraclostrobin, the percentage of total residues detected in each turf component for the second run are illustrated in Figure 7. Results for the first run were very similar (Figures 14-15). Azoxystrobin residues in roots accounted for $34-80 \%$ of all azoxystrobin measured throughout the sampling period (Figure 7, A). Only 5-20\% of all pyraclostrobin residues were detected in roots (Figure 7, B). Both azoxystrobin and pyraclostrobin are used successfully to treat root diseases (Gregos and Jung, 2003; Wong and Corza, 2005). However, if pyraclostrobin is primarily detected in the verdure/thatch layer, in order to achieve control of root diseases, pyraclostrobin must affect fungal growth and protect roots located in thatch. 
This research advances our understanding of how differences in fungicide phytomobility may affect the distribution of compounds applied to control root diseases. It also reinforces the concept of rapid dissipation of thiophanate-methyl into carbendazim. Accumulation and dissipation of residues in verdure and thatch is also supported. For propiconazole, azoxystrobin, and pyraclostrobin, root residues were relatively high 21 days after application. In order to appreciate the complete dissipation of fungicides in roots, future research should include a longer experimental period. Comparisons could be made among different cultural practices including irrigation, application volume, or use of wetting agents to improve fungicide delivery to the rhizosphere. An evaluation of fungicide distribution and dissipation in a sand based rootzone versus a native soil green also may provide some insight into inconsistencies observed by golf course superintendents. We did not correlate fungicide residues with effects on fungal growth. Such research is likely the next step in investigating control of root diseases with antifungal compounds. 


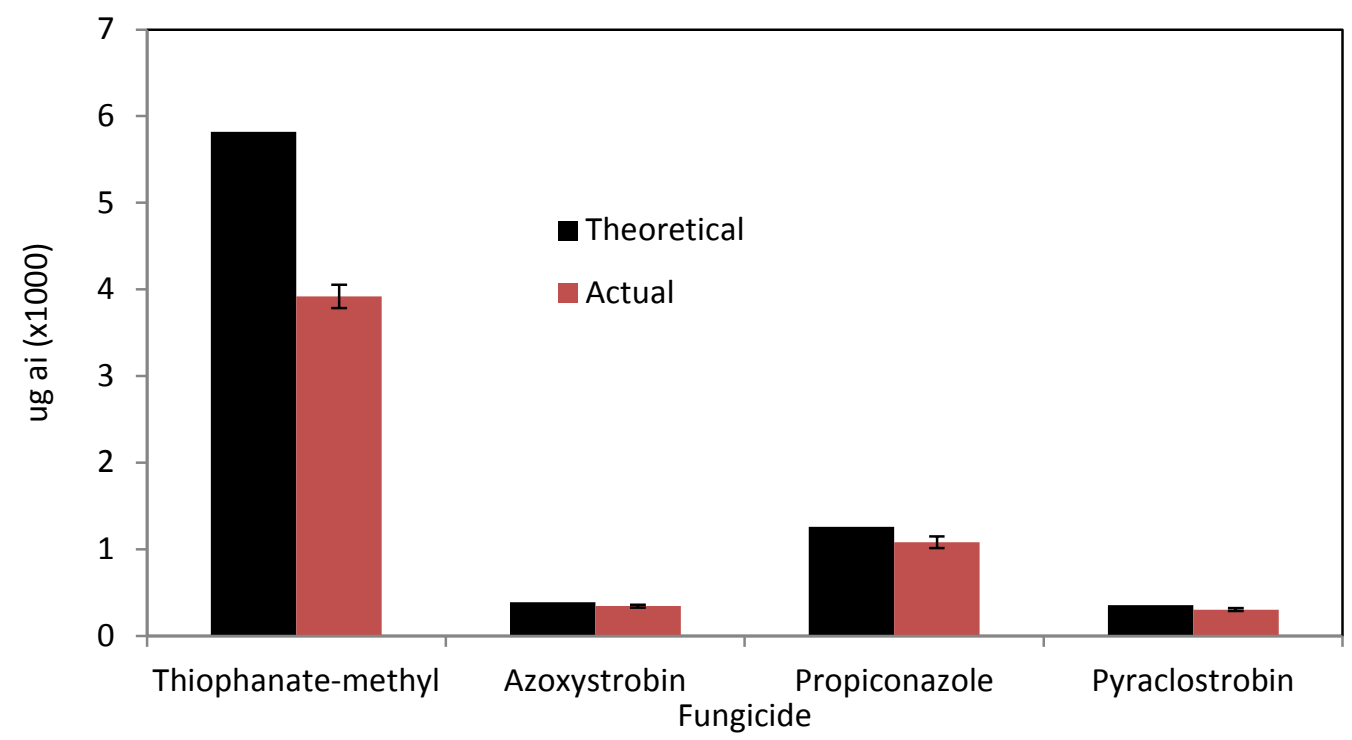

Figure 1. Spray capture conducted on glass petri plates with theoretical values based on fungicide label rates and actual values obtained using LC-MS/MS 

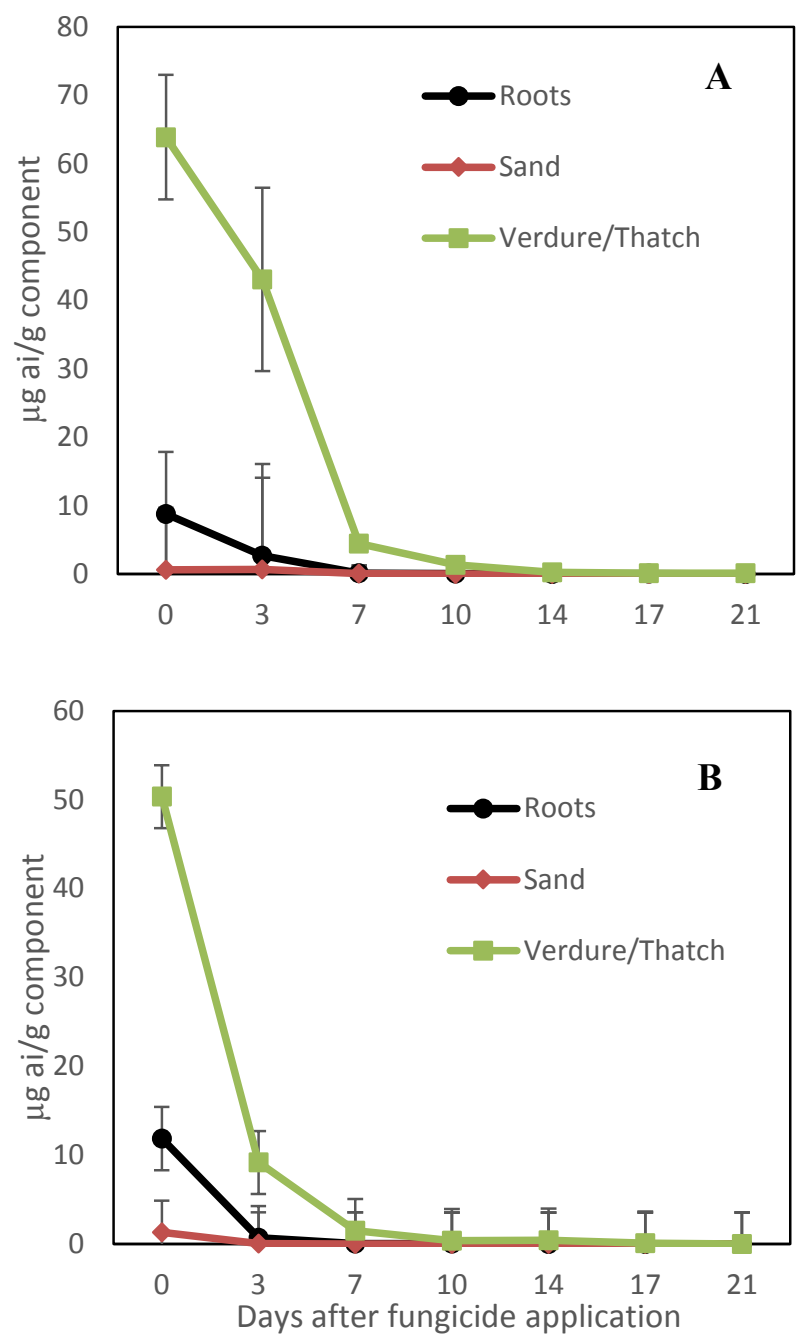

Figure 2. Spatial and temporal distribution of thiophanate-methyl on a sand based creeping bentgrass putting green. Experiments were conducted in July 2013 (A) and August 2013 (B). 

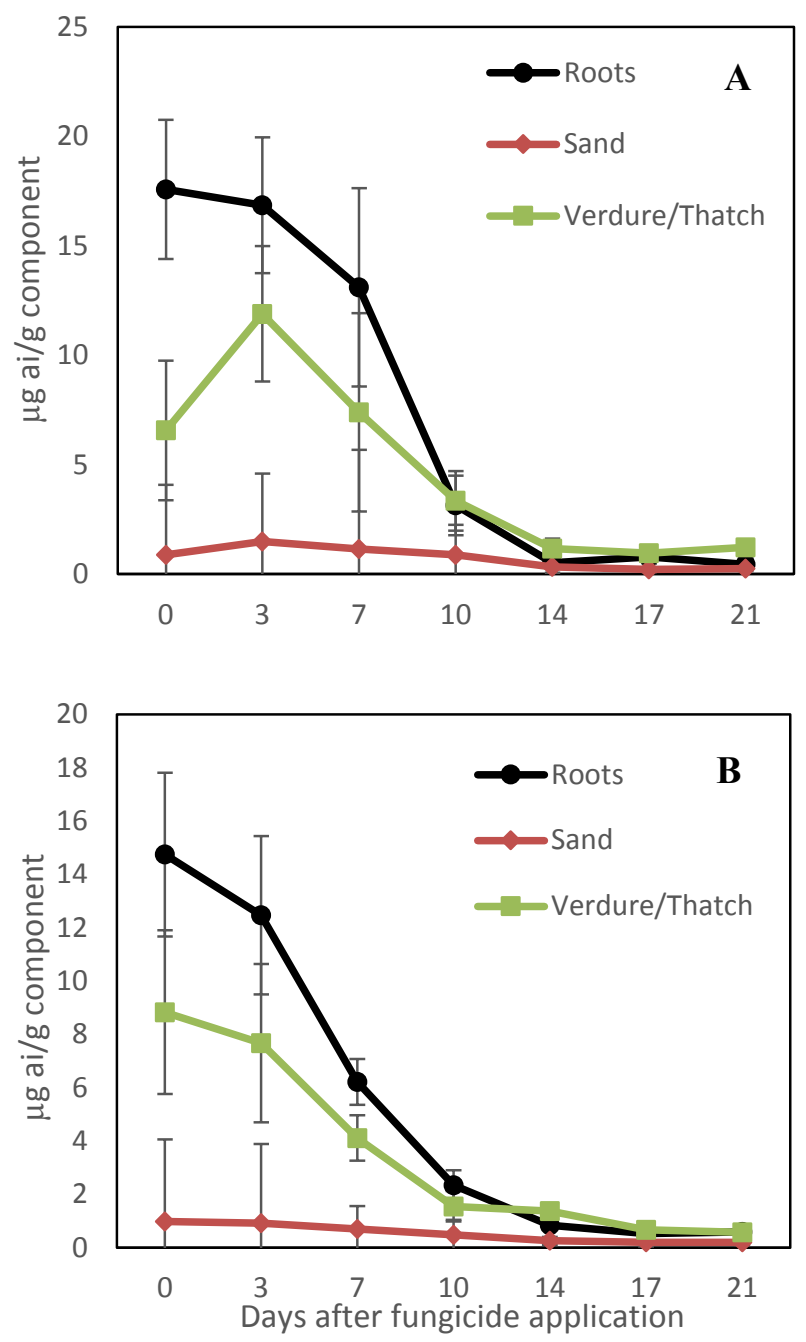

Figure 3. Spatial and temporal distribution of carbendazim on a sand based creeping bentgrass putting green. Experiments were conducted in July 2013 (A) and August 2013 (B). 

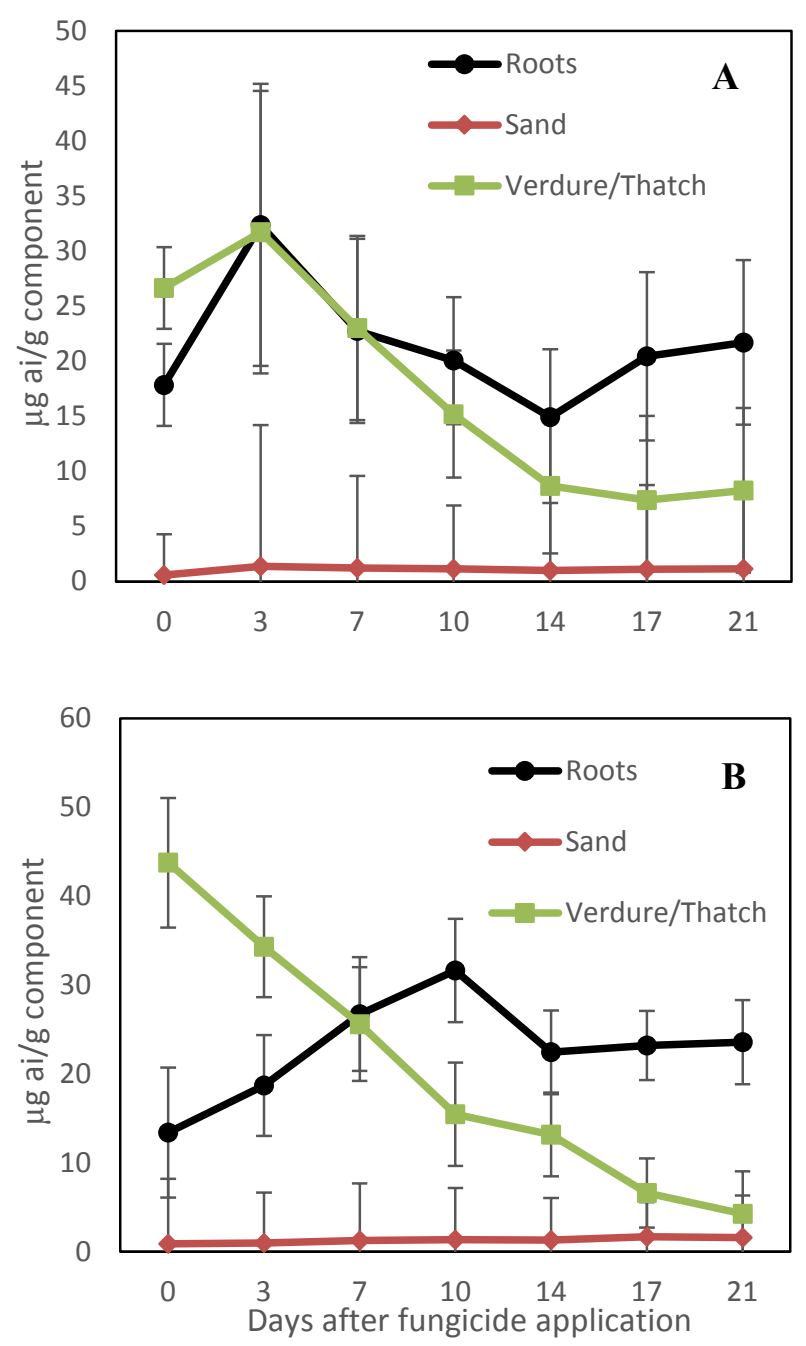

Figure 4. Spatial and temporal distribution of propiconazole on a sand based creeping bentgrass putting green. Experiments were conducted in July 2013 (A) and August 2013 (B). 

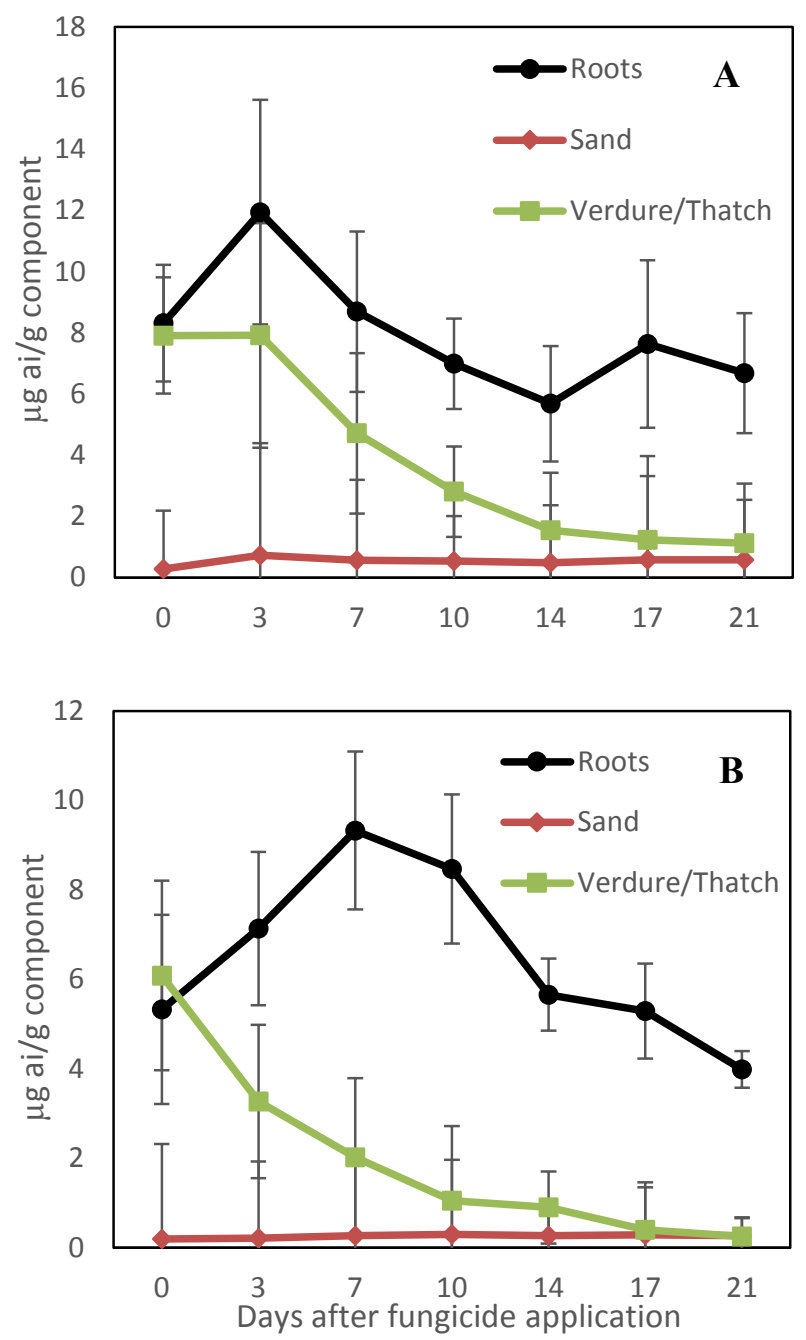

Figure 5. Spatial and temporal distribution of azoxystrobin on a sand based creeping bentgrass putting green. Experiments were conducted in July 2013 (A) and August 2013 (B). 

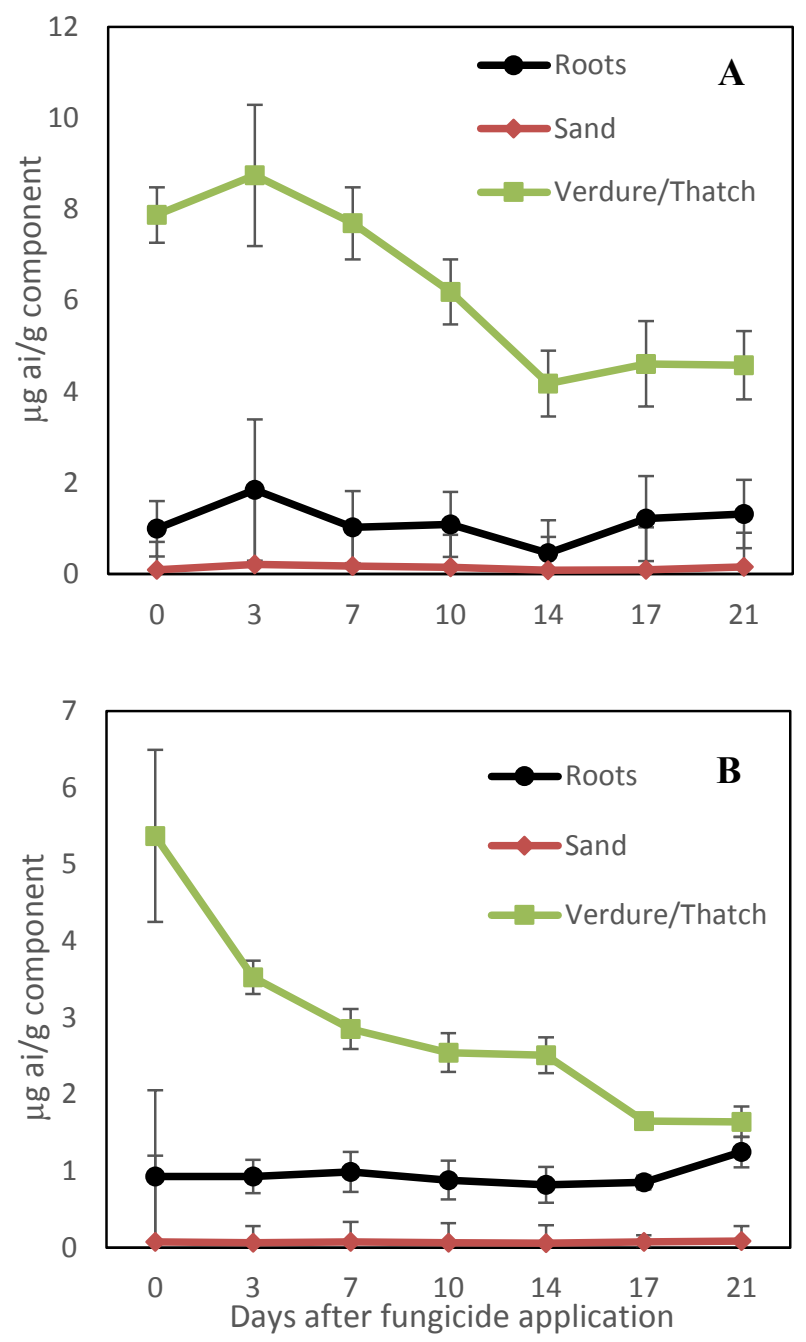

Figure 6. Spatial and temporal distribution of pyraclostrobin on a sand based creeping bentgrass putting green. Experiments were conducted in July 2013 (A) and August 2013 (B). 

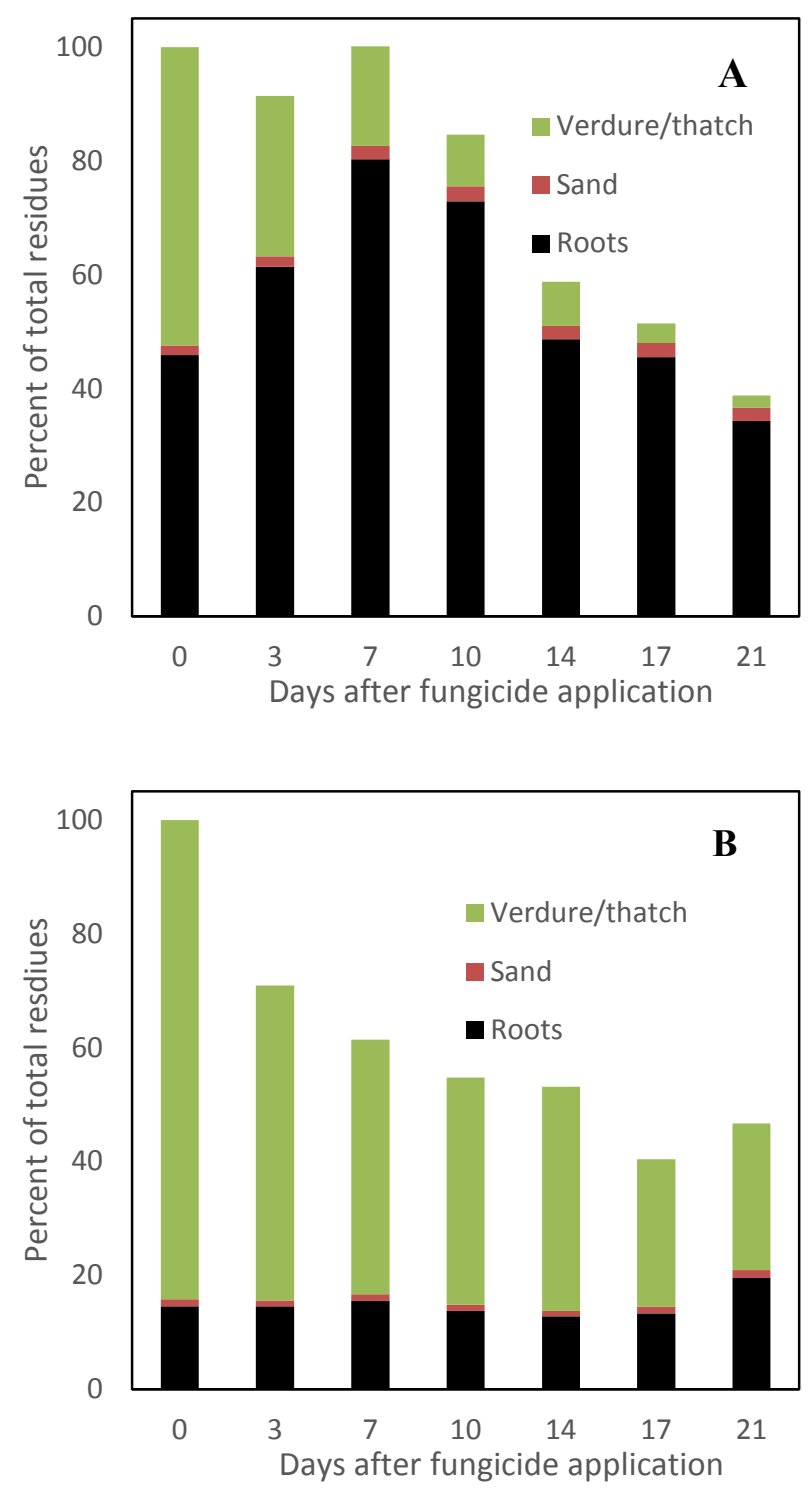

Figure 7. Percentage of initial azoxystrobin (A) and pyraclostrobin (B) residues detected in each turf component. Experiments were conducted in August 2013. 
Table 1. Fungicides applied to creeping bentgrass in 2013

\begin{tabular}{lllc}
\hline Fungicide & \multicolumn{1}{c}{ Fungicide Class } & Phytomobility & $\begin{array}{c}\text { Application Rate } \\
\left(\mathbf{k g ~ a . i . ~ h a} \mathbf{~ h}^{-1} \mathbf{)}\right.\end{array}$ \\
\hline Azoxystrobin & Quinone outside inhibitor (QoI) & Acropetal penetrant & 0.610 \\
Propiconazole & Demethylation inhibitor (DMI) & Acropetal penetrant & 1.980 \\
Thiophanate-methyl & Benzimidazole & Acropetal penetrant & 9.160 \\
Pyraclostrobin & Quinone outside inhibitor (QoI) & Local penetrant & 0.555 \\
\hline
\end{tabular}


Table 2. Tests of fixed effects for three turf components

\begin{tabular}{llllll}
\hline & & & Roots & Sand & Verdure/thatch \\
\cline { 4 - 6 } Source of Variation & Numerator DF & Denominator DF & $\operatorname{Pr}>\mathrm{F}$ & $\operatorname{Pr}>\mathrm{F}$ & $\operatorname{Pr}>\mathrm{F}$ \\
\hline Replication & 3 & 231 & $\mathrm{NS} \dagger$ & $* *$ & $\mathrm{NS}$ \\
Fungicide & 4 & 231 & $* * *$ & $* * *$ & $* * *$ \\
Day & 6 & 231 & $* * *$ & $* * *$ & $* * *$ \\
Fungicide*Day & 24 & 231 & $* * *$ & $* * *$ & $* * *$ \\
Run & 1 & 231 & NS & $*$ & $* * *$ \\
Fungicide*Run & 4 & 231 & NS & $* * *$ & $* * *$ \\
Day*Run & 6 & 231 & NS & $* * *$ & $* *$
\end{tabular}

* Significant at the 0.05 probability level

** Significant at the 0.01 probability level

*** Significant at the 0.001 probability level

$\dagger$ NS, not significant at the 0.05 probability level 
Table 3. First order dissipation half-lives (DHL) of five fungicides applied in July and August of 2013

\begin{tabular}{|c|c|c|c|c|c|c|}
\hline \multirow[b]{3}{*}{ Fungicide } & \multicolumn{6}{|c|}{ Dissipation half-life (days) } \\
\hline & \multicolumn{3}{|c|}{ July 2013} & \multicolumn{3}{|c|}{ August 2013} \\
\hline & Roots & Sand & Verdure/thatch & Roots & Sand & Verdure/thatch \\
\hline Azoxystrobin & $12.7 \mathrm{~b}$ & $\mathrm{NA} \dagger$ & $6.5 \mathrm{ab}$ & $10.1 \mathrm{ab}$ & NA & $4.7 \mathrm{~b}$ \\
\hline Propiconazole & $14.5 b$ & NA & $10.1 \mathrm{~b}$ & $24.4 \mathrm{~b}$ & NA & $6.3 b$ \\
\hline Thiophanate-methyl & $2.6 \mathrm{a}$ & $2.8 \mathrm{a}$ & $2.3 \mathrm{a}$ & $2.4 \mathrm{a}$ & $2.9 \mathrm{a}$ & $1.9 \mathrm{a}$ \\
\hline Carbendazim & $4.0 \mathrm{a}$ & $7.0 \mathrm{~b}$ & $5.6 \mathrm{ab}$ & $4.7 \mathrm{a}$ & $9.3 b$ & $5.4 \mathrm{~b}$ \\
\hline Pyraclostrobin & NA & NA & $18.9 \mathrm{c}$ & NA & NA & $13.5 \mathrm{c}$ \\
\hline
\end{tabular}


Table 4. Least squares means for the ANOVA model based on roots

\begin{tabular}{lllllllll}
\hline Fungicide & Estimate & Standard Error & DF & t Value & Pr $>|\mathbf{t}|$ & Alpha & Lower & Upper \\
\hline Carbendazim & 6.4428 & 0.7268 & 231 & 8.86 & $<.0001$ & 0.05 & 5.0107 & 7.8749 \\
Thiophanate-methyl & 1.7587 & 0.7268 & 231 & 2.42 & 0.0163 & 0.05 & 0.3266 & 3.1908 \\
Azoxystrobin & 7.2277 & 0.7268 & 231 & 9.94 & $<.0001$ & 0.05 & 5.7956 & 8.6598 \\
Propiconazole & 22.1438 & 0.7268 & 231 & 30.47 & $<.0001$ & 0.05 & 20.7117 & 23.5759 \\
Pyraclostrobin & 1.0451 & 0.7268 & 231 & 1.44 & 0.1518 & 0.05 & -0.3870 & 2.4772 \\
\end{tabular}

Table 5. Least squares means for the ANOVA model based on sand

\begin{tabular}{lllllllll}
\hline Fungicide & Estimate & Standard Error & DF & t Value & Pr $>|\mathbf{t}|$ & Alpha & Lower & Upper \\
\hline Carbendazim & 0.6409 & 0.03446 & 231 & 18.60 & $<.0001$ & 0.05 & 0.5730 & 0.7088 \\
Thiophanate-methyl & 0.2045 & 0.03446 & 231 & 5.93 & $<.0001$ & 0.05 & 0.1366 & 0.2724 \\
Azoxystrobin & 0.4002 & 0.03446 & 231 & 11.61 & $<.0001$ & 0.05 & 0.3323 & 0.4681 \\
Propiconazole & 1.2063 & 0.03446 & 231 & 35.00 & $<.0001$ & 0.05 & 1.1384 & 1.2743 \\
Pyraclostrobin & 0.1060 & 0.03446 & 231 & 3.07 & 0.0024 & 0.05 & 0.03807 & 0.1739 \\
\hline
\end{tabular}

Table 6. Lease squares means for the ANOVA model based on verdure/thatch

\begin{tabular}{lllllllll}
\hline Fungicide & Estimate & Standard Error & DF & t Value & Pr $>|\mathbf{t}|$ & Alpha & Lower & Upper \\
\hline Carbendazim & 4.0990 & 0.7039 & 231 & 5.82 & $<.0001$ & 0.05 & 2.7122 & 5.4858 \\
Thiophanate-methyl & 12.5342 & 0.7039 & 231 & 17.81 & $<.0001$ & 0.05 & 11.1474 & 13.9210 \\
Azoxystrobin & 2.9473 & 0.7039 & 231 & 4.19 & $<.0001$ & 0.05 & 1.5605 & 4.3341 \\
Propiconazole & 18.8817 & 0.7039 & 231 & 26.83 & $<.0001$ & 0.05 & 17.4949 & 20.2685 \\
Pyraclostrobin & 4.5705 & 0.7039 & 231 & 6.49 & $<.0001$ & 0.05 & 3.1837 & 5.9573 \\
& & & & & & & &
\end{tabular}


REFERENCES 


\section{REFERENCES}

Anastassiades, M., S.J. Lehotay, D. Stajnbaher and F.J. Schenck. 2003. Fast and easy multiresidue method employing acetonitrile extraction/partitioning and dispersive solidphase extraction for the determination of pesticide residues in produce. J. AOAC Int. 86: 412-431.

Chapman, R.A., C. Harris, P. Moy and K. Henning. 1986. Biodegradation of pesticides in soil: Rapid degradation of isofenphos in a clay loam after a previous treatment. $\mathrm{J}$. Environ. Sci. Health Part B 21: 269-276.

Clarke, B.B. and A.B. Gould. 1993. Turfgrass patch diseases caused by ectotrophic rootinfecting fungi. APS Press, St. Paul, MN.

Daniels, J. and R. Latin. 2013. Residual efficacy of fungicides for controlling brown patch on creeping bentgrass fairways. Plant Dis. 97: 1620-1625.

Davis, D.B. and P.H. Dernoeden. 1991. Summer patch and Kentucky bluegrass quality as influenced by cultural practices. Agron. J. 83: 670-677.

Dell, C.J., C.S. Throssell, M. Bischoff and R.F. Turco. 1994. Estimation of sorption coefficients for fungicides in soil and turfgrass thatch. J. Environ. Qual. 23: 92-96.

Dernoeden, P.H. 1993. Integrating strategies for the management of patch diseases caused by root invading ectotrophic fungi. In: B. B. Clarke and A. B. Gould, editors, Turfgrass patch diseases caused by ectotrophic root-infecting fungi. APS Press, St. Paul, MN. p. 123-161.

Earlywine, D. and G.L. Miller. 2012. Evaluation of fall preventative fungicides for summer patch control on Kentucky bluegrass, 2010-2011. Plant Dis. Manag. Rep. 6:T021. doi: 10.1094/PDMR06.

Fleeker, J.R., H.M. Lacy, I.R. Schultz and E.C. Houkom. 1974. Persistence and metabolism of thiophanate-methyl in soil. J. Agric. Food Chem. 22: 592-595. 
Frederick, E.K., M. Bischoff, C.S. Throssell and R.F. Turco. 1994. Degradation of chloroneb, triadimefon, and vinclozolin in soil, thatch, and grass clippings. Bull. Environ. Contam. Toxicol. 53: 536-542.

Frederick, E.K., C.S. Throssell, M. Bischoff and R.F. Turco. 1996. Fate of vinclozolin in creeping bentgrass turf under two application frequencies. Bull. Environ. Contam. Toxicol. 57: 391-397.

Gardner, D.S. and B.E. Branham. 2001. Effect of turfgrass cover and irrigation on soil mobility and dissipation of mefenoxam and propiconazole. J. Environ. Qual. 30: 16121618.

Gardner, D.S., B.E. Branham and D.W. Lickfeldt. 2000. Effect of turfgrass on soil mobility and dissipation of cyproconazole. Crop Sci. 40: 1333-1339.

Ghosh, R.K. and N. Singh. 2009. Effect of organic manure on sorption and degradation of azoxystrobin in soil. J. Agric. Food Chem. 57: 632-636.

Gregos, J. and G. Jung. 2003. Evaluation of spring fungicide treatments for take-all patch in colonial bentgrass, 2002. F\&N Tests 58:T008. doi: 10.1094/FN58.

Horst, G., P. Shea, N. Christians, D. Miller, C. Stuefer-Powell and S. Starrett. 1996. Pesticide dissipation under golf course fairway conditions. Crop Sci. 36: 362-370.

Hsu, J. 1996. Multiple comparisons: theory and methods. CRC Press, Boca Raton, FL.

Hurto, K., A. Turgeon and M. Cole. 1979. Degradation of benefin and DCPA in thatch and soil from a Kentucky bluegrass (Poa pratensis) turf. Weed Sci. 27: 154-157.

Hurto, K.A., A.J. Turgeon and L.A. Spomer. 1980. Physical characteristics of thatch as a turfgrass growing medium. Agron. J. 72: 165-167.

Jackson, N. 1993. Geographic distribution, host range, and symptomatology of patch diseases caused by soilborne ectotrophic fungi. In: B. B. Clarke and A. B. Gould, editors, Turfgrass patch diseases caused by ectotrophic root-infecting fungi. APS Press, St. Paul, MN. p. 17-39.

Kackley, K.E., A.P. Grybauskas, P.H. Dernoeden and R.L. Hill. 1990a. Role of drought stress in the development of summer patch in field-inoculated Kentucky bluegrass. Phytopathology 80: 655-658. 
Kackley, K.E., A.P. Grybauskas, R.L. Hill and P.H. Dernoeden. 1990b. Influence of temperature-soil water status interactions on the development of summer patch in $P o a$ spp. Phytopathology 80: 650-655.

Landschoot, P.J. and N. Jackson. 1987. The Phialophora state of a Magnaporthe sp. causes summer patch disease of Poa pratensis L. and Poa annua L. Phytopathology 77: 119.

Landschoot, P.J. and N. Jackson. 1989. Magnaporthe poae sp. nov., a hyphopodiate fungus with a Phialophora anamorph from grass roots in the United States. Mycological Research 93: 59-62.

Latin, R. 2006. Residual efficacy of fungicides for control of dollar spot on creeping bentgrass. Plant Dis. 90: 571-575.

Latin, R. 2011. A practical guide to turfgrass fungicides. APS Press, St. Paul, MN.

Liu, L.X. and T. Hsiang. 1994. Bioassays for benomyl adsorption and persistence in soil. Soil Biol. Biochem. 26: 317-324.

Liu, L.X. and T. Hsiang. 1996. Estimating benzimidazole residues in thatch and turfgrass by bioassay. Pestic. Sci. 46: 139-143.

Magri, A. and D.A. Haith. 2009. Pesticide decay in turf: A review of processes and experimental data. J. Environ. Qual. 38: 4-12.

Majumdar, P.R., G.W. Towers, E.N. Weibel, J.N. DiMarco, M. Peacos and B.B. Clarke. 2000. Evaluation of chemical and biological fungicides for the control of summer patch, 1999. F\&N Tests 55:513. doi: 10.1094/FN55.

McDonald, S.J., M.A. Fidanza and D. Hudson. 2007. Curative control of take-all patch in a creeping bentgrass fairway as influenced by fungicides and plant nutrition, 2006. Plant Dis. Manag. Rep. 1:T052. doi: 10.1094/PDMR01.

Mitkowski, N.A. and B. Boesch. 2006. Efficacy of mid-season fungicide application for curative control of summer patch, 2005. F\&N Tests 61:T002. doi: 10.1094/FN61.

Pinto, C.G., M.E.F. Laespada, S.H. Martín, A.M.C. Ferreira, J.L.P. Pavón and B.M. Cordero. 2010. Simplified QuEChERS approach for the extraction of chlorinated compounds from soil samples. Talanta 81:385-391. 
Reddy, S.N., S. Gupta and V.T. Gajbhiye. 2013. Effect of moisture, organic matter, microbial population and fortification level on dissipation of pyraclostrobin in soils. Bull. Environ. Contam. Toxicol. 91: 356-361.

Schumann, G.L., J.M. Clark, J.J. Doherty and B.B. Clarke. 2000. Application of DMI fungicides to turfgrass with three delivery systems. In: J. M. Clark and M. P. Kenna, editors, Fate and management of turfgrass chemicals. American Chemical Society, Washington, D.C. p. 150-163.

Sigler, W., Z. Reicher, C. Throssell, M. Bischoff and R. Turco. 2003. Sorption and degradation of selected fungicides in the turfgrass canopy. Water Air Soil Pollut. 142: 311-326.

Sigler, W.V., C.P. Taylor, C.S. Throssell, M. Bischoff and R.F. Turco. 2000.

Environmental fates of fungicides in the turfgrass environment: A minireview. In: J. Clark, editor, Fate and management of turfgrass chemicals. American Chemical Society, Washington, DC. p. 127-149.

Singh, N. and P. Dureja. 2009. Effect of biocompost-amendment on degradation of triazole fungicides in soil. Bull. Environ. Contam. Toxicol. 82: 120-123.

Slade, E., R.A. Fullerton, A. Stewart and H. Young. 1992. Degradation of the dicarboximide fungicides iprodione, vinclozolin and procymidone in Patumahoe clay loam soil, New Zealand. Pestic. Sci. 35: 95-100.

Smiley, R. and M.C. Fowler. 1984. Leptosphaeria korrae and Phialophora graminicola associated with Fusarium blight syndrome of Poa pratensis in New York. Plant Dis. 68: 440-442.

Smiley, R., M.C. Fowler and R. Kane. 1985. Temperature and osmotic potential effects on Phialophora graminicola and other fungi associated with patch diseases of Poa pratensis. Phytopathology 75: 1160-1167.

Smiley, R.W. 1993. Historical perspective of research on ectotrophic root-infecting pathogens of turfgrasses. In: B. B. Clarke and A. B. Gould, editors, Turfgrass patch diseases caused by ectotrophic root-infecting fungi. APS Press, St. Paul, MN. p. 1-15.

Soika, M.D. and L.P. Tredway. 2010a. Control of summer patch on Kentucky bluegrass with fungicides in Raleigh, North Carolina, 2008-2009. Plant Dis. Manag. Rep. 4:T021. doi: 10.1094/PDMR04. 
Soika, M.D. and L.P. Tredway. 2010b. Evaluation of registered and experimental fungicides for control of summer patch in Kentucky bluegrass, 2009. Plant Dis. Manag. Rep. 4:T020. doi: 10.1094/PDMR04.

Thom, E., J.C.G. Ottow and G. Benckiser. 1997. Degradation of the fungicide difenoconazole in a silt loam soil as affected by pretreatment and organic amendment. Environ. Pollut. 96: 409-414.

Thompson, D.C., B.B. Clarke and J.R. Heckman. 1995. Nitrogen form and rate of nitrogen and chloride application for the control of summer patch in Kentucky bluegrass. Plant Dis. 79: 51-56.

Thompson, D.C., B.B. Clarke and D.Y. Kobayashi. 1996. Evaluation of bacterial antagonists for reduction of summer patch symptoms in Kentucky bluegrass. Plant Dis. 80: $856-862$.

Turgeon, A.J. 1991. Turfgrass management. Prentice-Hall Inc., Englewood Cliffs, NJ.

Vincelli, P., E. Dixon, D. Williams and P. Burrus. 2004. Influence of fungicides on turf quality in a mixed creeping bentgrass/Poa annua soil-based green, 2003. F\&N Tests 59:T020. doi: 10.1094/FN59.

Walker, A., P.A. Brown and A.R. Entwistle. 1986. Enhanced degradation of iprodione and vinclozolin in soil. Pestic. Sci. 17: 183-193.

Wong, F.P. and J. Corza. 2005. Control of summer patch and anthracnose on an annual bluegrass green in southern California, 2004. F\&N Tests 60:T058. doi: 10.1094/FN60.

Wu, L., G. Liu, M.V. Yates, R.L. Green, P. Pacheco, J. Gan, et al. 2002. Environmental fate of metalaxyl and chlorothalonil applied to a bentgrass putting green under southern California climatic conditions. Pest Manag. Sci. 58: 335-342. 


\section{APPENDICES}




\section{Appendix A}

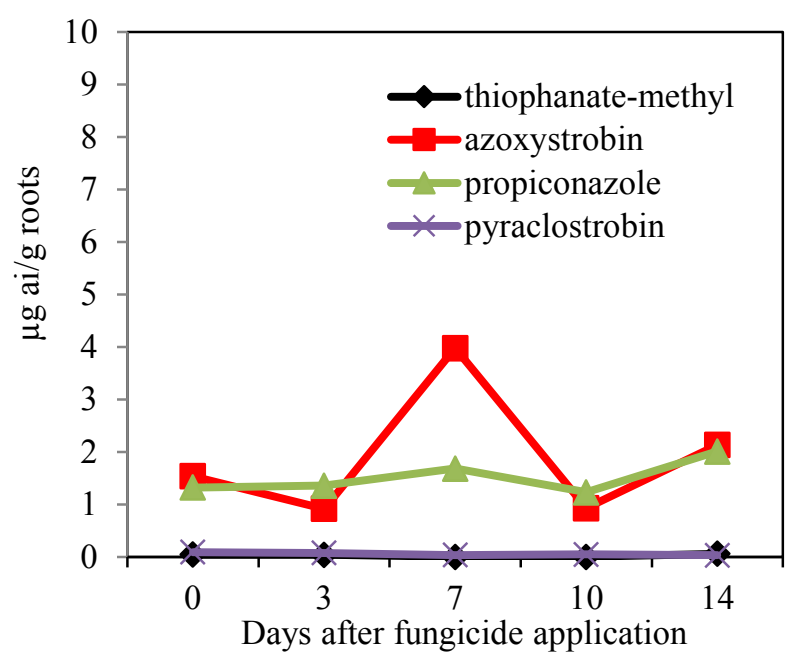

Figure 8. Temporal distribution of four fungicides in creeping bentgrass roots. Preliminary experiment, September 2011.

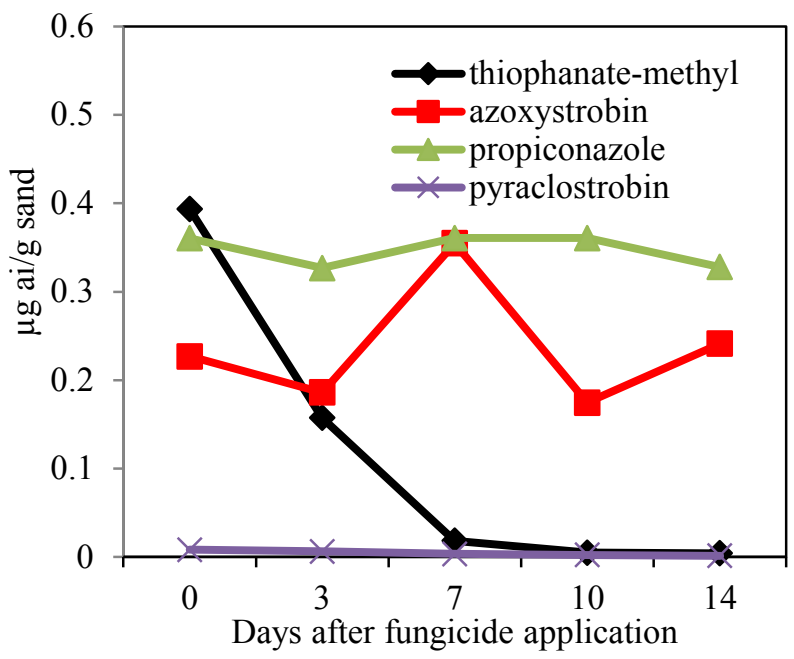

Figure 9. Temporal distribution of four fungicides in creeping bentgrass rhizosphere sand. Preliminary experiment, September 2011. 


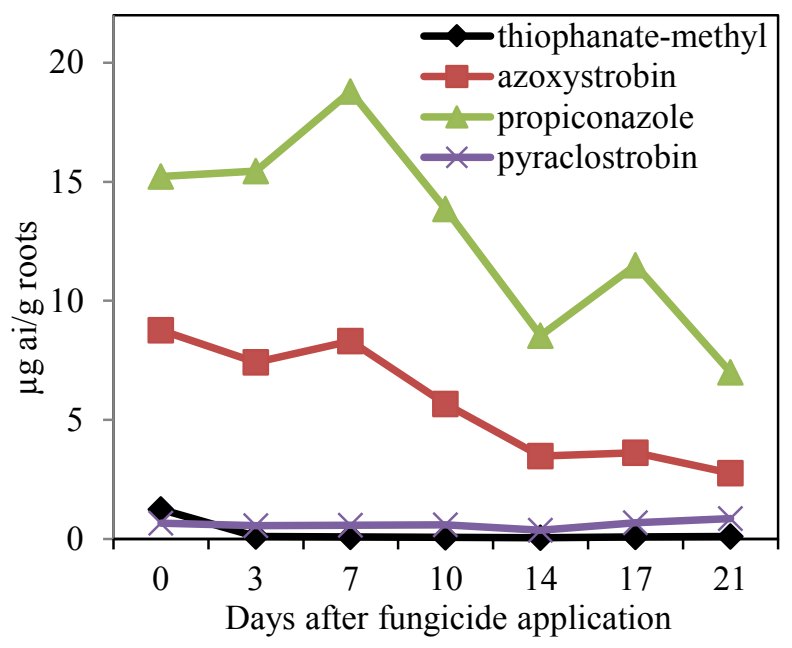

Figure 10. Temporal distribution of four fungicides in creeping bentgrass roots. Preliminary experiment, July 2012.

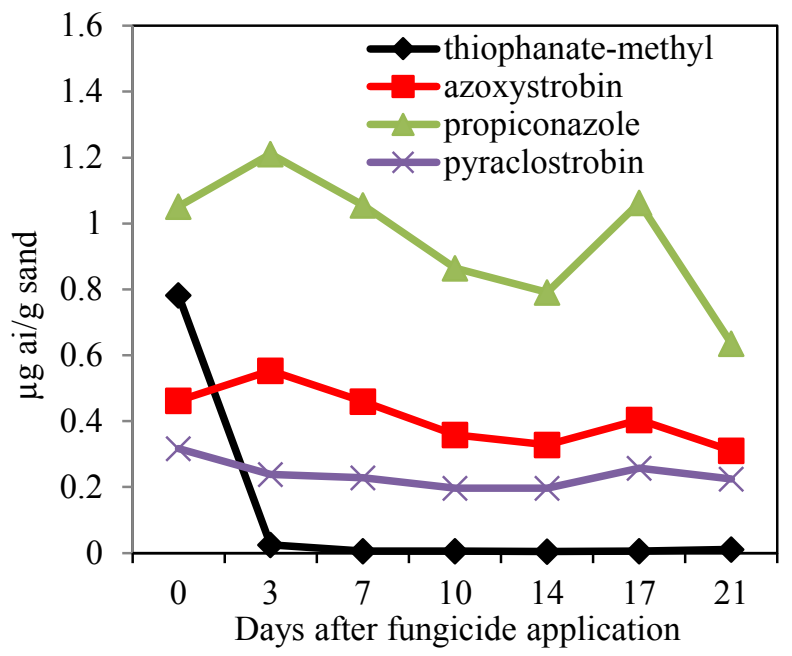

Figure 11. Temporal distribution of four fungicides in creeping bentgrass rhizosphere sand. Preliminary experiment, July 2012. 


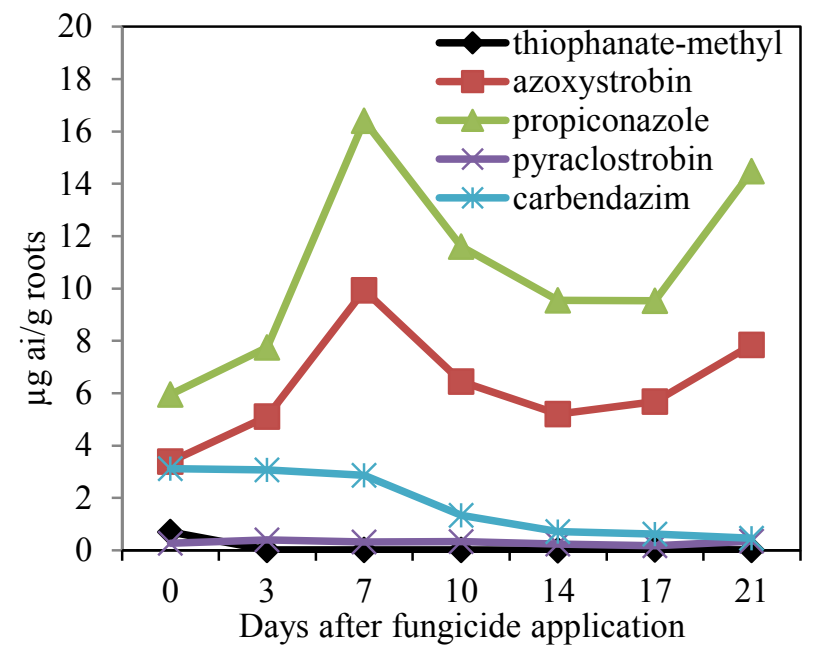

Figure 12. Temporal distribution of five fungicides in creeping bentgrass roots. Preliminary experiment, August 2012.

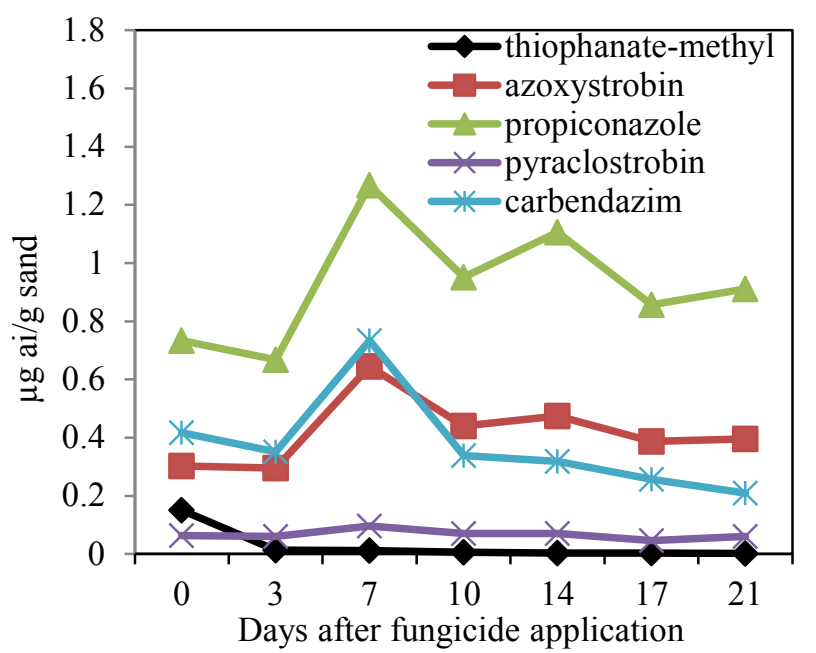

Figure 13. Temporal distribution of five fungicides in creeping bentgrass rhizosphere sand. Preliminary experiment, August 2012. 


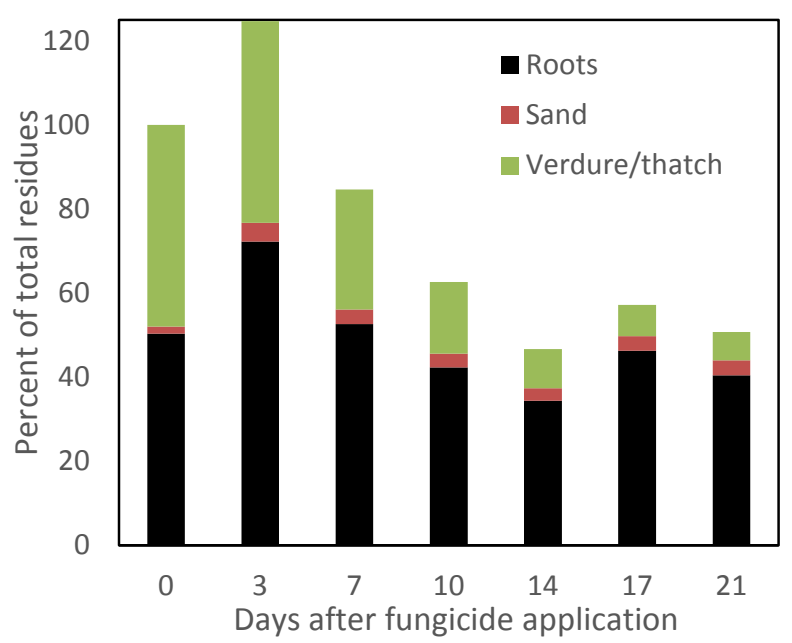

Figure 14. Percentage of initial azoxystrobin residues detected in each turf component. Experiment was conducted in July 2013.

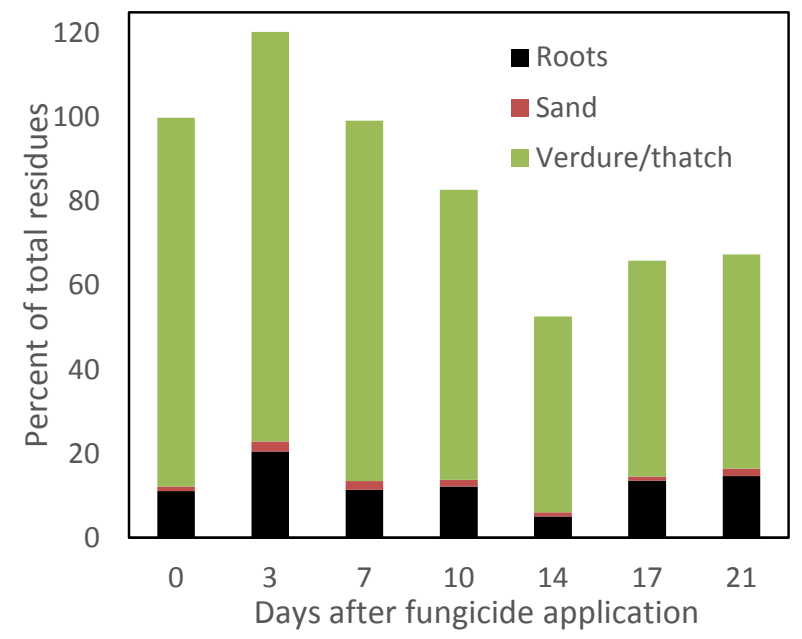

Figure 15. Percentage of initial pyraclostrobin residues detected in each turf component. Experiment was conducted in July 2013. 


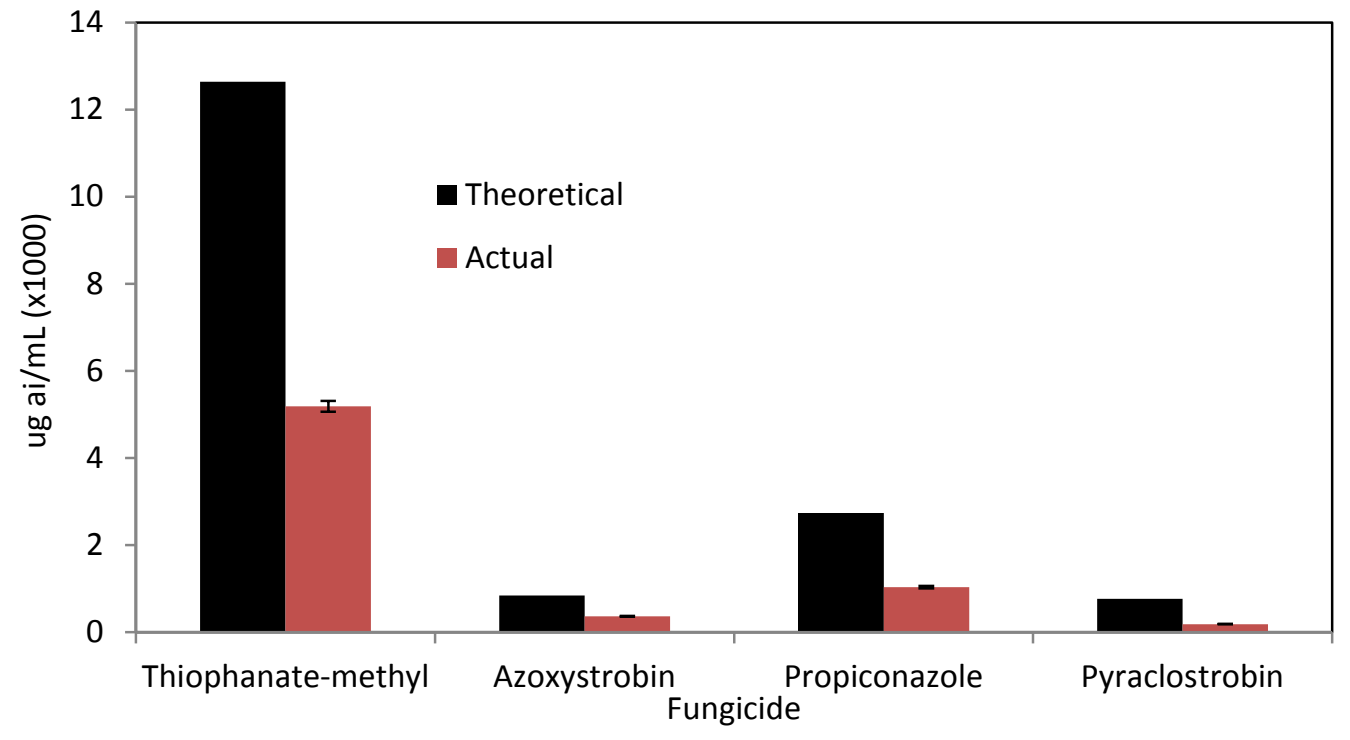

Figure 16. Spray capture collected from bottle with theoretical values based on fungicide label rates and actual values obtained using LC-MS/MS 
Table 7. Tests of fixed effects for roots

\begin{tabular}{lcccc}
\hline Effect & Numerator DF & Denominator DF & F Value & Pr $>$ F \\
\hline Fungicide & 4 & 231 & 137.62 & $<.0001$ \\
Day & 6 & 231 & 6.25 & $<.0001$ \\
Replication & 3 & 231 & 0.72 & 0.5435 \\
Run & 1 & 231 & 0.52 & 0.4720 \\
Fungicide*Day & 24 & 231 & 4.16 & $<.0001$ \\
Fungicide*Run & 4 & 231 & 1.84 & 0.1211 \\
Day*Run & 6 & 231 & 1.51 & 0.1742 \\
\hline
\end{tabular}


Table 8. Tests of fixed effects for sand

\begin{tabular}{lcccc}
\hline Effect & Numerator DF & Denominator DF & F Value & Pr $>$ F \\
\hline Fungicide & 4 & 231 & 162.21 & $<.0001$ \\
Day & 6 & 231 & 6.29 & $<.0001$ \\
Replication & 3 & 231 & 4.03 & 0.0080 \\
Run & 1 & 231 & 5.05 & 0.0256 \\
Fungicide*Day & 24 & 231 & 8.50 & $<.0001$ \\
Fungicide*Run & 4 & 231 & 13.38 & $<.0001$ \\
Day*Run & 6 & 231 & 5.08 & $<.0001$ \\
\hline
\end{tabular}

Table 9. Tests of fixed effects for verdure/thatch

\begin{tabular}{lcccc}
\hline Effect & Numerator DF & Denominator DF & F Value & Pr $>$ F \\
\hline Fungicide & 4 & 231 & 95.70 & $<.0001$ \\
Day & 6 & 231 & 95.99 & $<.0001$ \\
Replication & 3 & 231 & 2.28 & 0.0802 \\
Run & 1 & 231 & 11.25 & 0.0009 \\
Fungicide*Day & 24 & 231 & 24.90 & $<.0001$ \\
Fungicide*Run & 4 & 231 & 7.58 & $<.0001$ \\
Day*Run & 6 & 231 & 3.78 & 0.0013 \\
\hline
\end{tabular}


Table 10. Tests of fixed effects for July 2013 run

\begin{tabular}{lcccc}
\hline Effect & Numerator DF & Denominator DF & F Value & Pr $>$ F \\
\hline Fungicide & 4 & 360 & 32.39 & $<.0001$ \\
Day & 6 & 360 & 14.87 & $<.0001$ \\
Replication & 3 & 360 & 2.41 & 0.0665 \\
Component & 2 & 360 & 70.88 & $<.0001$ \\
Fungicide*Day & 24 & 360 & 2.53 & 0.0001 \\
Fungicide*Component & 8 & 360 & 31.63 & $<.0001$ \\
Day*Component & 12 & 360 & 5.49 & $<.0001$ \\
\hline
\end{tabular}

Table 11. Tests of fixed effects for August 2013 run

\begin{tabular}{lcccc}
\hline Effect & Numerator DF & Denominator DF & F Value & Pr $>$ F \\
\hline Fungicide & 4 & 360 & 90.39 & $<.0001$ \\
Day & 6 & 360 & 14.05 & $<.0001$ \\
Replication & 3 & 360 & 1.05 & 0.3715 \\
Component & 2 & 360 & 82.64 & $<.0001$ \\
Fungicide*Day & 24 & 360 & 3.28 & $<.0001$ \\
Fungicide*Component & 8 & 360 & 84.48 & $<.0001$ \\
Day*Component & 12 & 360 & 7.33 & $<.0001$ \\
\hline
\end{tabular}




\section{Appendix B}

\section{B.1 Summer patch}

Before 1984, all patch diseases with similar symptoms to summer patch were described as Fusarium blight (Davis and Dernoeden, 1991). Smiley and Fowler (1984) then described a separate pathogen, Phialophora graminicola, to be the causal agent of the summer patch disease. Landschoot and Jackson (1987) then concluded that the causal agent was misidentified, and designated it as Magnaporthe poae. Symptoms of summer patch occur as patches of dead turf that are $2.5-5 \mathrm{~cm}$ in diameter. These patches can increase up to $30 \mathrm{~cm}$ in diameter which results in coalescing patches that can leave large areas of turf devastated. The frog-eye symptom occurs when weeds or other grass species colonize the center of the patch creating a ring of symptomatic often necrotic turf and is characteristic of summer patch. Dark brown ectotrophic runner hyphae are observed growing on the roots and crowns of infected plants (Kackley et al., 1990a). This disease poses a risk wherever high quality turf is grown, including annual bluegrass golf greens and fairways, Kentucky bluegrass sports fields, or Kentucky bluegrass or fine fescue home lawns. Summer patch severity can be reduced with an integrated approach of cultural practices that promote healthy plants and roots, but in areas where disease tolerance is very low, fungicides are an important aspect of control.

Magnaporthe poae is a hyphopodiate, root-infecting fungus with a Phialophora anamorph. The perithecia can be single or gregarious with a globose 
body (252-556 $\mu \mathrm{m}$ diameter) and cylindrical neck (357-756 $\mu \mathrm{m}$ long). Asci contained in the perithecia are numerous, cylindrical, straight or slightly curved, and 63-108 $\mu \mathrm{m}$ long. The ascospores contained in the asci are fusoid, $23-42 \mu \mathrm{m}$ long, $2-$ septate at maturity, with the end cells hyaline and the intermediate cells thick walled. Superficial hyphae growing on plant roots are sparse, brown, and septate. Typically $2-5 \mu \mathrm{m}$ in diameter and can be found singly or together with $2-3$ strands. The hyphopodia are globose and can occur singly or in groups on roots or crowns. Swollen hyphal cells often populate cortical cells. Phialides that produce conidia are hyaline, 6-15 $\mu \mathrm{m}$ long, straight or curved, and are borne on lateral branches or terminally. Cultures grown on potato dextrose agar contain appressed mycelium that are initially hyaline while slowing turning grey or olivaceous brown with thick strands of dark mycelium growing from the center of the colony. Leading hyphae are wavy, often curling back toward the center. Old colonies are olivaceous brown or black. Magnaporthe poae is a heterothallic species that requires two mating types to achieve sexual reproduction in vitro (Landschoot and Jackson, 1989).

Symptoms of the summer patch disease begin to develop under high temperature and low soil moisture conditions and can appear from June through September. Although symptoms can be exacerbated by drought conditions, drought is not a predisposing factor to disease development (Jackson, 1993). Weakened and impaired root systems are unable to support above ground plant tissues and therefore symptoms appear during dry conditions. It was found that M. poae attained maximum growth on PDA and incited the most damage on inoculated plants at 25$30{ }^{\circ} \mathrm{C}$ (Kackley et al., 1990b). 


\section{B.2 Summer patch control}

Cultural control options play a large part in the control of summer patch. It can be more severe on compacted and poorly drained areas. Aerification is recommended to reduce soil bulk density, increase rooting, and help reduce symptom expression. Soil moisture is another important factor in the development of summer patch. Kackley et al. (1990a) showed that summer patch symptoms were most severe in turf that was kept in non-drought conditions. Symptoms were suppressed in treatments that were irrigated deeply and infrequently versus lightly and frequently (Davis and Dernoeden, 1991). This type of irrigation regime generally results in deeper root systems. Turgeon (1991) stated that lower mowing heights result in aesthetically more pleasing turfs but also reduce the turfs defenses against environmental and disease pressures. Davis and Dernoeden (1991) found that summer patch damage was less severe in Kentucky bluegrass turf maintained at 7.6 $\mathrm{cm}$ versus turf maintained at $3.8 \mathrm{~cm}$. Susceptibility of plants to M. poae (reported as Phialophora graminicola) was more pronounced in turf mown at $2 \mathrm{~cm}$ versus unmowed (Smiley et al., 1985). Sulfur coated urea, urea, ammonium chloride, and sodium nitrate were evaluated for their effects on summer patch severity. Sulfur coated urea reduced the severity of summer patch the most, while sodium nitrate treatments yielded the most severe summer patch symptoms. The authors stated that the beneficial results are most likely due to the acidifying and slow release effects of the sulfur coated urea. Sodium nitrate may have increased severity because it reduced rooting and did not acidify the soil (Davis and Dernoeden, 1991). Thompson et al. 
(1995) showed that in 'Fylking' Kentucky bluegrass summer patch symptoms and rhizosphere $\mathrm{pH}$ were slightly reduced by the application of ammonium sulfate in the first year. The following year resulted in delayed onset of summer patch symptoms and great reduction in patch development and soil $\mathrm{pH}$. Summer patch severity was reduced by up to $75 \%$ in the high ammonium sulfate treatments $\left(196 \mathrm{~kg} \mathrm{~N} \mathrm{ha}^{-1} \mathrm{yr}^{-1}\right)$. Biological control of summer patch has not been extensively studied. Thompson et al. (1996) tested 10 different bacterial strains known for their ability to control soilborne pathogens on agronomic crops for their ability to suppress summer patch. All ten bacterial strains showed some level of suppression in agar plates. Five significantly reduced disease symptoms in the growth chamber. Two strains reduced summer patch in two different field trials. Enterobacter cloacae EcH-1 and Bacillus subtilis D-39Sr reduced symptoms by $34-49 \%$ and $39-53 \%$ respectively. 


\section{Appendix C}

\section{C.1 Intrinsic activity of fungicides against Magnaporthe poae}

Dilution plate assays were used to assess the sensitivity of Magnaporthe poae to four fungicides. Potato dextrose agar (PDA) was amended with 0.001, 0.01, 0.1, 1, and $10 \mathrm{ppm}$ of each fungicide active ingredient. LD50 (fungicide concentration at which colony growth was reduced by $50 \%$ when compared to colony growth on non-amended PDA) was calculated after regressing relative growth percentages over log 10 fungicide concentration. LD50 values for thiophanate-methyl, propiconazole, azoxystrobin, and pyraclostrobin were $0.53,0.004,0.02$, and $0.001 \mathrm{ppm}$, respectively. 


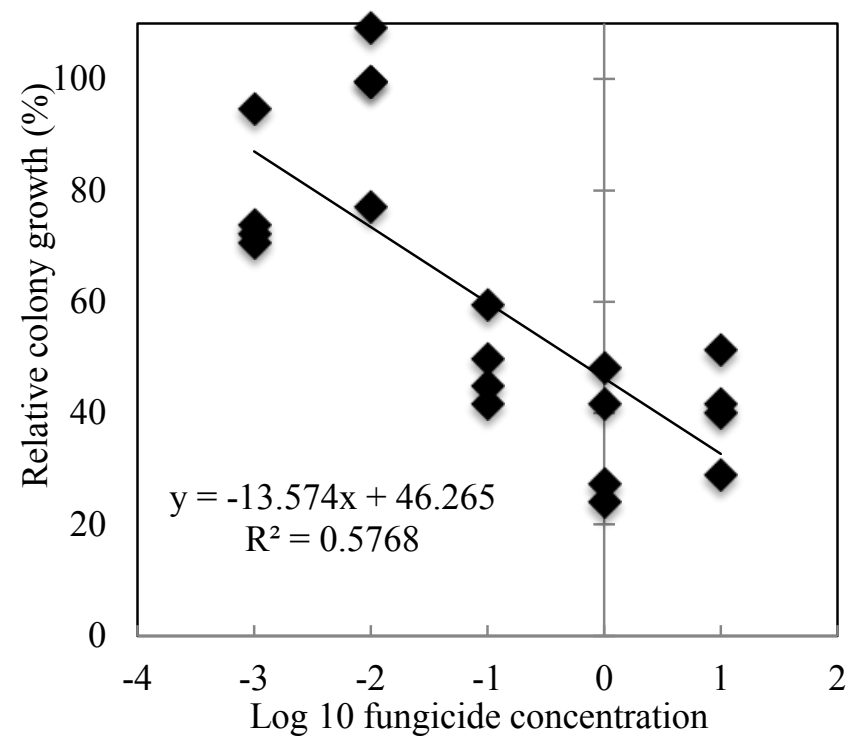

Figure 17. Linear regression of relative colony growth data of an isolate of $M$. poae against thiophanate-methyl.

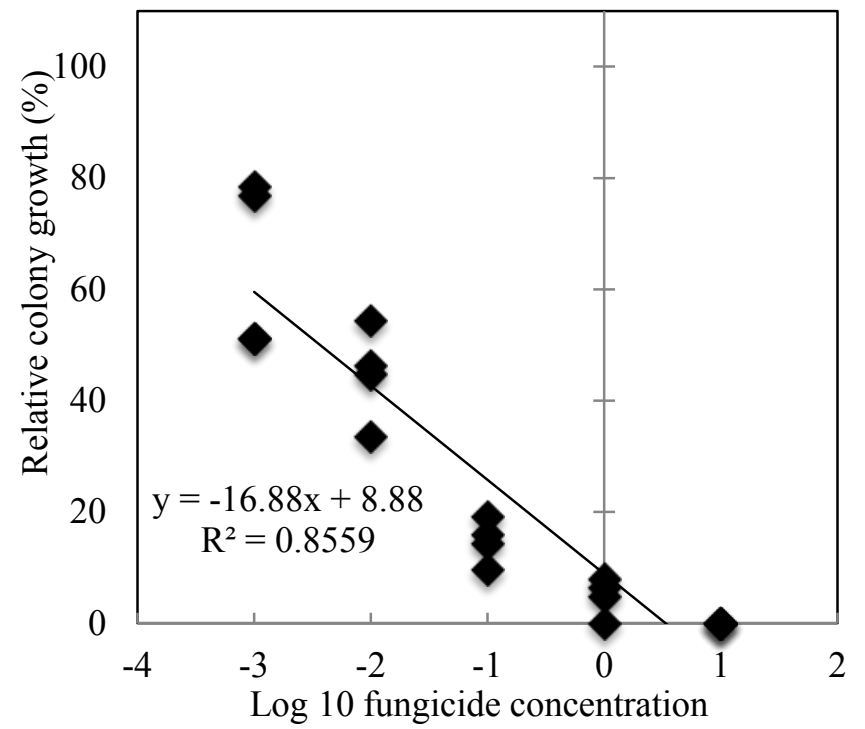

Figure 18. Linear regression of relative colony growth data of an isolate of M. poae against propiconazole. 


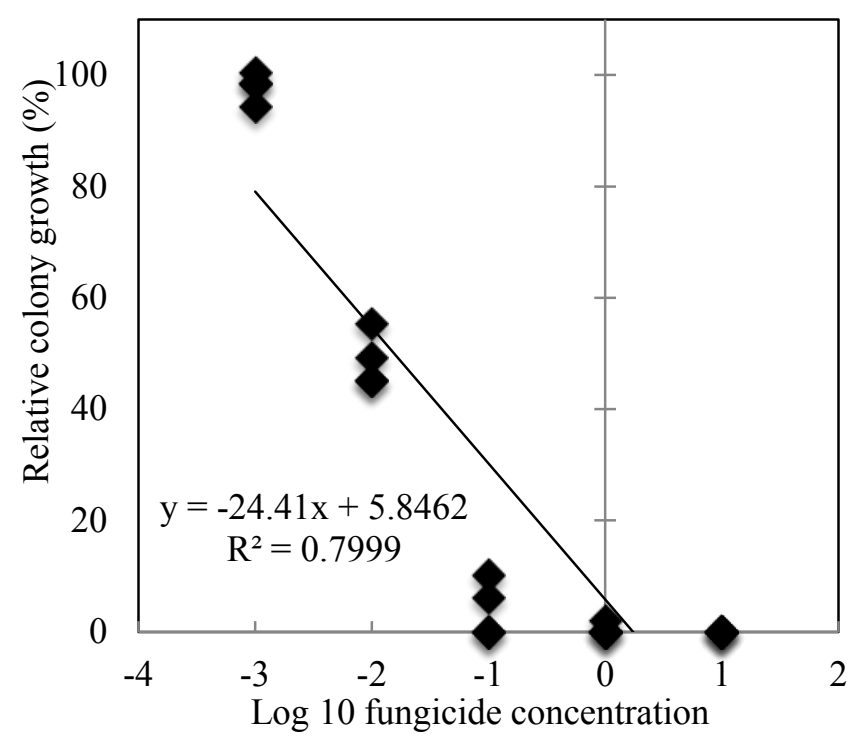

Figure 19. Linear regression of relative colony growth data of an isolate of M. poae against azoxystrobin.

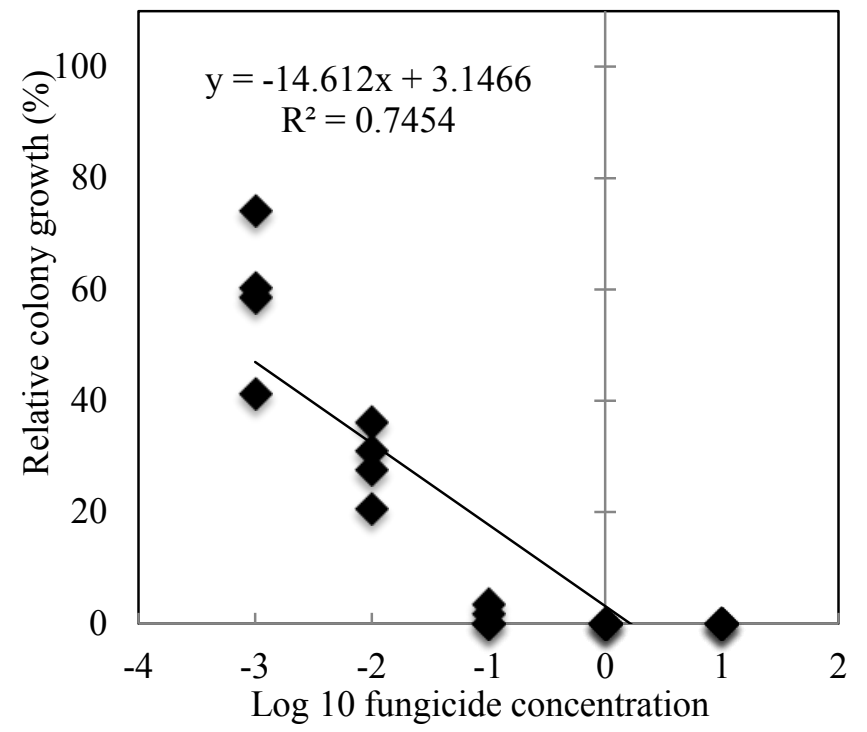

Figure 20. Linear regression of relative colony growth data of an isolate of M. poae against pyraclostrobin. 